ISSN: 2667-4432

Journal of Universal History Studies (JUHIS) • Vol. I • Issue 1 • 2018 • pp. 44-79

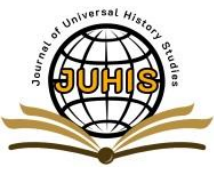

\title{
Türk Siyasal Hayatınnn Vakitsiz Doğan Çocuğu: Terakkiperver Cumhuriyet Fırkası ${ }^{1}$ Ersin MÜEZZINOĞLU ${ }^{2}$ \\ Karabük University, Associate Professor, Department of International Relations, Karabük, Turkey \\ Received- Accepted: 02.12.2018-20.12.2018 \\ Research Article
}

\section{$\ddot{O} \mathbf{z}$}

Yeni Türk devletinin ilk muhalefet partisi olan Terakkiperver Cumhuriyet Frrkasının (TPCF) kuruluşu, faaliyetleri ve kapatıllşı erken Cumhuriyet Dönemi’nin ve Türk siyasal hayatının önemli ve tartışmalı konularnndan biridir. Teşekkülüyle birlikte yeni Türkiye'yi çok partili hayatla da tanıştran TPCF, önemi ölçüsünde araştrrlmaya konu edilmemiştir. TPCF, içinde eski İtihat ve Terakkinin bazı nüfuzlu şahsiyetlerini barındırması, çalışma ve teșkilatlanma usulleri, hatta aldı̆̆ı isim bakımından İttihat ve Terakkinin istihalesi ve yeni bir teşkilatla tekrar faaliyete geçmesi olarak değerlendirilmiştir. Frrka aynı zamanda 1923 seçimleriyle tasfiye olan İkinci Grubun da bir sığıağı ve fikirlerini tahakkuk ettirmek için vasitası olmuştur. TPCF, Cumhuriyetin ilk yıllarındaki iktidar-muhalefet ilişkileri ve yaşanan tartışmalar yönüyle de üzerinde durulmaya değerdir. Uzun ömürlü olmayan bu firkanı, vakitsiz doğduğu ve yaşama olasilğı̆ olmadığı ileri sürülmüştür. Çalısmada ağıllkh olarak dönemin gazeteleri ve hatıratlar ışı̆ğnda; TPCF’nin ortaya çıkıs nedenleri, programı ve faaliyetleri, Cumhuriyet Halk Furkası ile ilişkileri, kapatılmasının gerekçe ve etkenleri üzerinde durulmuş ve mevcut literatür de gözden geçirilerek TPCF hakkında daha shhatli bir değerlendirme yapılması amaçlanmışstr.

Anahtar Kelimler: Terakkiperver Cumhuriyet Frkasi(TPCF), Cumhuriyet Halk Frrkası(CHF), Türk Siyasal Hayatı, İttihat ve Terakki, Şeyh Sait İsyanı

\section{The Premature Of The Turkish Political Life: Progressive Republican Party}

\begin{abstract}
The establishment, activities and closing of the first opposition of the New Turkish Republic, the Progressive Republican Party (Terakkiperver Cumhuriyet Frkasi), is one of the most important and discussed issues of the Turkish Political Life and early Republican Era. This development starting also the multi-party system in new Turkey is not a subject of significant researches until now. the Progressive Republican Party is considered as a new formation of previous Party of Union and Progress due to inclusion of some preponderant figures of previous Party of Union and Progress, working and organization procedures, and even the similarity of the titles. This party is also a shelter for the Second Group, which is discharged with the 1923 elections to state their opinions. the Progressive Republican Party is of interest with regards to power and opposition relations and the relevant discussions during the early years of the Republic. This short-term party is claimed as premature and that it does not have a chance to live. The study mainly focuses on the reasons creating the the Progressive Republican Party, activities of the party, relations with the The Republican Peoples Party, and factors behind its closure based on the newspapers of the term and memoirs thereof. Thus, the current literature is reviewed and a more accurate assessment of the party is aimed.
\end{abstract}

Keywords: The Progressive Republican Party, Republican People's Party, Turkish Political Life, Party of Union and Progress, Sheikh Said Rebellio

\footnotetext{
${ }^{1}$ Bu makale Prof. Dr. Mustafa Keskin danışmanlığında hazırlanıp 2012 yılında Erciyes Üniversitesi Sosyal Bilimler Enstitüsüne sunulan "Bir İttihatçı Eğitimci Ahmet Şükrü Bey” başlıklı doktora tezinden üretilmiştir.

2 ersinmuezzinoglu@karabuk.edu.tr, ORCID: 0000-0001-7095-7869, This article is analyzed by two reviewers and it is screened for the resembalance rate by the editor. (Bu makale iki hakem tarafından incelenmiş ve editör tarafından benzerlik oranı taramasından geçirilmiştir)
} 
Türk Siyasal Hayatının Vakitsiz Doğan Çocuğu: Terakkiperver Cumhuriyet Fırkası/Ersin MÜEZZINNOĞLU

\section{Giriş}

Bir muhalif firkanın teşekkülü ve böylece ülkede çok partili yaşama geçiş, hayli girift hadiseler üzerine gerçekleşmiştir. Esasen Halk Fırkasının bölünüp yeni bir firkanın ortaya çıkışı, ani bir gelişmeden ziyade tarihi biraz gerilere uzanan Millî Mücadele liderleri arasındaki görüş ayrılıklarının bir neticesi olarak görülmelidir. Bu cümleden olarak ilk ihtilaf Başvekil Rauf Bey ile Hariciye Vekili İsmet Paşa arasında Lozan Konferansı müzakerelerinin yürütülmesi konusunda ortaya çıkmıştır. Gazi Mustafa Kemal Paşa, bu hadisede İsmet Paşa'nın yanında yer almıştır. Bunun üzerine Rauf Bey, İsmet Paşa ile aralarında oluşan vaziyet ve kendisine yapılan tarizler üzerine artı beraber çalışamayacaklarını ve yüz yüze gelemeyeceklerini, sulhu imzalayan İsmet Paşa'nın tatbikini de kendisinin yapmasına firsat vermek düşünceleri ile başvekillikten çekilme kararı almıştır (Orbay, 2004, s. 432-435,447).

Ardından Cumhuriyet'in ilanında izlenen yol Millî Mücadele liderleri arasında esaslı bir kırılma yaratmıştır. Gazi Mustafa Kemal, Halifenin konumunu tehdit ederken kendi konumumu kuvvetlendiren Cumhuriyet'in ilanı işini, Osmanlı hanedanına bağlılı̆̆ bilinen ve bu reformdan memnun olmayacakların düşündüğü tanınmış bazı simaların, Rauf Bey ve Karabekir Paşa gibi, Ankara dışında bulunduğu sırada gerçekleştirmiştir. Büyük ölçüde sun'i yaratılan ve idare edilen hükümet buhranı sonucunda çabucak Cumhuriyetin ilan edilişi Rauf Bey ve arkadaşlarının şaşkınlığına ve endişeye kapılmalarına yol açmıştır. İlanı müteakiben bazı İstanbul gazetelerine açıklama yapan Rauf Bey, Cumhuriyet'e karşı olmamakla birlikte anayasanın mecliste ve kamuoyunda tartışılmadan alelacele ve usule uygun düşmeyen şsekilde değiştirildiğini öne sürmüş ve bu görüşleriyle halkın düşüncelerine tercüman olduğunu dile getirmiştir (Zürcher, 2007, s. 53-54). Açıllama Halk Firkasında homurtulara ve Rauf Bey'in Cumhuriyet aleyhtarı olduğu şeklinde değerlendirmelere yol açmıştır. Rauf Bey'den beyanatını geri alması istenmiş, o da ülkenin selameti için zararlı olduğunu söyleyerek bundan imtina etmiştir. İsmet Paşa "cumhuriyet hakîmiyet-i milliyenin tekâmülüdür" görüşünü savunurken, Rauf Bey ise "cumhuriyetin tekâmülü hâkimiyet-i milliyedir" demiştir. Rauf Bey ayrıca, İsmet Paşa'ya hitaben "mutlaka muhalif bir firka kurmam isteniliyor. $\mathrm{Bu}$, vatanın yükssek menfaatleriyle bağdaştırlamaz. Muhalif firka yapmayacağım. Hüküm sizindir. Karar sizindir, fakat vicdan benimdir” sözlerini kullanmıştır. Bu açıklamalarına rağmen, Rauf Bey'in lider, İsmail Canbolat Bey'in kâtib-i umumi olacağı yeni bir firkanın kurulacağına dair haberler basında yer bulmuştur. Hatta bazı mebuslar İstanbul'a gelerek hazırlığa dahi başlamışlardır (Tevhid-i Efkâr, 29 Kasım 1923, s. 3). Özellikle İstanbul'daki birtakım gazeteler de Cumhuriyet'in ilanını soğuk karşılamıştır. Bunlardan Tevhid-i Efkâr'da 'Efendiler İstical Ediyorsunuz' başlı̆ğyla bir makale yayınlayan Ebüzziya Bey, böyle mühim bir kararın halkla paylaşılması gerektiğini, 1 Kasım 1922'de acele edildiğini ama o zaman bunu mazur gösterecek ordunun İstanbul'a girmesi meselesi gibi bir durumun söz konusu olduğunu söylemiştir (Tevhid-i Efkâr, 30 Ekim 1923, s. 1). Rauf Bey anılarında, kendisine atfedilen acele edildiğine dair ifadelerin kendi görüşlerini yansıtmadığını ve yanlış anlaşıldığını, zaten fiilen bir Cumhuriyet'in mevcut olduğunu belirtmiştir (Orbay, 2004, s. 449). 
Journal of Universal History Studies (JUHIS) • Vol. I • Issue 1 • 2018 • pp. 44-79

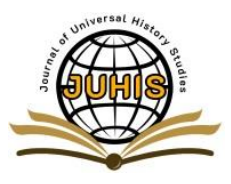

Refet Paşa'ya gelince; O, işlerin yolunda gitmediğini düşünerek önce Mayls 1923’te mebusluktan ayrılma kararı almıştır. Çözüm olarak vaktiyle "inkılâba pişdâr” olan bazı arkadaşlarının aralarındaki mesafeyi kaldırmak gerektiğine inanmıştır. Refet Paşa'nın sözünü ettiği Amasya Protokolü' dür ${ }^{3}$ ve $\mathrm{O}$, bu protokole imza koymuş bazı arkadaşlarının iktidar mevkiinden uzak kalmalarını eleştirmiştir. Diğer paşaların askerlikten istifa kararı aldığı günlerde, yani 1923 Ekim'i sonlarında, istifasını geri almıştır (Mehmet Asım, 29 Ekim 1924, s. 1). Gazetelere yansıyan bilgilere göre Refet Paşa'nın istifasında Musul hudutlan meselesinin ortaya çıardığı son durum, meclisin acele bir şekilde toplantıya davet edilmesi ve birçok arkadaşının ısrarı gibi etkenler rol oynamıştır (Son Telgraf, 14 Ekim 1924, s. 1). Bu gelişme, Halk Fırkası çevrelerinde yeni firka kuruluşu için bir adım olarak görülmüştür. Müfrit Halk Frrkalı Yazar-Mebus Karaosmanoğlu'nun sonradan yaptığı şu analiz, Refet Paşa'nın tespitleriyle örtüşmektedir: Asıl dava Mustafa Kemal Paşa'nın eski silah ve mücadele arkadaşlarıyla birleşmesi ve yalnız İsmet Paşa'ya bağlanıp kalmamasıydı (Karaosmanoğlu, 1984, s. 83).

Bir diğer önemli aktör Ali Fuat Paşa, Cumhuriyet'in ilanı hakkında verdiği demeçte şunları söylemiştir (Tevhid-i Efkâr, 31 Ekim 1923, s. 2): "Hükûmet şeklinin değiştirilmesine acele edilmemeli, ülkenin acil meseleleri için hükûmet mevcut ve çalışıyor. Hükûmet makinesi yürüyor. Yürümüyorsa bu Teşkilat-1 Esasiye'den değildir'”.

TPCF'ye yakın gazetelere göre Cumhuriyet'in ilanı şeklen de tartışmalıdır. Zira 286 mebustan oluşan meclis, 158 mebus ile bu kararı almıştır. Oysa önemli meselelerde sülüsan (üçte iki) çoğunluk Teşkilat-1 Esasiye Kanunu'nun amir bir hükmüdür. Bu üçte iki çoğunluk için ise 190 mebus gereklidir (Tevhid-i Efkâr, 31 Ekim 1923, s. 2).

Bu durumda Gazi Mustafa Kemal Paşa'nın arkadaşlan ile aralarında oluşan bu yeni vaziyet ve ihtilaflara nasıl baktığının anlaşılması önemlidir. Rauf Bey'in başbakanlıktan ayrıldığı gün Ali Fuat Paşa ile Gazi Mustafa Kemal Paşa arasında geçen şu diyalog bu noktada önemli bilgiler sunmaktadır. Ali Fuat Paşa, Gazi Paşa'ya: "senin şimdi apotreslerin (havariler) kimlerdir? diye sormuş o da "benim apotreslerim yoktur memlekete ve millete kimler hizmet eder, hizmet-i liyakat ve kudretini gösterirse apotresler onlardır", demiş̧ir. Gazi Paşa'nın bu sözü, "ilk beşler” arasındaki ihtilafin artık düşüncede kalmayıp su yüzz̈ne çıktığını, geçmişteki hukukun halihazıra bir tesirinin olmadığını göstermiştir (Okyar, 1980, s. 340).

Yukarıdaki bilgiler ışığında; Millî Mücadele liderleri arasındaki ihtilafların yeni olmadığı, meselenin yeni Türk devletinin nasıl bir devlet olacağı ile ne şekilde ve kimler tarafindan yönetileceği noktasında düğümlendiği, Gazi Mustafa Kemal Paşa'dan ayrı düşen arkadaşlarının gidişattan rahatsız olmalarına rağmen bir müddet için sabredip bekledikleri, fakat sonrasında aradaki ihtilafların gün yüzüne çıktığı ve yeni bir firkanın ortaya çıkması neticesini verdiği anlaşılır.

\footnotetext{
${ }^{3}$ Amasya Tamimi Refet Paşa tarafindan protokol olarak isimlendirilmiştir.
} 
Türk Siyasal Hayatının Vakitsiz Doğan Çocuğu: Terakkiperver Cumhuriyet Fırkası/Ersin MÜEZZINNOĞLU

\section{Terakkiperver Cumhuriyet Furkasının Kuruluşuna Doğru}

Yeni bir firkanın teşekkülü konusu önce bazı gazetelerde haberleştirilmiştir. Bu gelişme, iktidar firkasına yakın gazetelerde ilgi ve tepkiyle karşılanmıştır. Benizade Hamdi Bey’in "Yeni Fırka" başlıklı yazısında bunu görmek mümkündür. Ona göre inkılâbın tarihi henüz yenidir. $\mathrm{Bu}$ yeni tarihin ilk aşamalarında firkacıllk mücadelelerine yer verilmemesi gerekir. Bugün kurulacak yeni bir firka, arzulanmasa dahi Cumhuriyet'e zarar verebilecek bir tohumdan başka bir şey olmaz. Demokrasi kavramı firkaların çokluğunu gerektirse de demokratların, cumhuriyetçilerin, yenileşme yanlılarının, inkılâbını yeni yapmış bir memlekette ilk işleri firkalar icat etmek değildir. Bu yönüyle hakikat kurama feda edilemez. Benizade Hamdi Bey bu noktada ülkenin yeni bir firkaya değil, müspet işlerin yapılmasına ihtiyaç duyduğu ve mebusların bu amaç için çalışmaları gerektiği, yoksa hükûmet devirmenin, bugünden yarına vekil değiştirmenin, firka oyunu oynamanın bir hayır ve menfaat getirmeyeceği görüşünü dile getirmiştir (Benizade Hamdi, 23 Ekim 1924, s. 2).

Yine aynı gazetede Yunus Nadi Bey imzalı bir yazıda yeni firka teşkili ile ilgili söylentiler karşısında açık ve örtülü uyarılara yer verilmiştir. Buna göre, yeni vücut bulacak bir firka Hürriyet ve İtilaflara kucak açmaktan başka bir şey değildir. Halk Fırkası ise savaş sırasında ve sonrasında müspet işler yapmıştır. Yunus Nadi Bey bu hatırlatmalardan sonra, 'Dikkat ediniz efendiler, önünüzde uçurumlar var'" diyerek bir uyarıyla yazısını sonlandırmıştır(Yunus Nadi, 31 Ekim 1924, s. 1).

Birkaç gün sonra aynı yazarın "İktidar İbtilası” başlıklı bir başka yazısında, Meşrutiyet idarelerinin tecrübeleri altında görünen manzaranın gerçek manasının şöyle olduğu anlatılmıştır (Yunus Nadi, 2 Kasım 1924, s. 1): "Buna iktidar ibtilası ttlak olunur ki hükûmet için hükûmet düsturunda hülasa olunabilir. Eğer Cumhuriyet'in Meşrutiyet'ten bir farkı olacaksa bu devrede o ihtiras ve ibtilaya artık meydan verilmemelidir”. Görüldüğü üzere Halk Fırkasına yakın bazı önemli isimler yeni firkanın oluşumuna soğuk bakmışlar, onu sadece bir "ihtiras eseri”" olarak görmüşler ve yeni firkaya bazı uyarılarda bulunmuşlardır.

Peki görevi dolayısıyla fahri olarak Halk Fırkasının riyasetini de elinde tutan Reisicumhur Gazi Paşa, yeni firka haberleri ile ilgili ne düşünmekteydi? Gazi, TPCF'nin kuruluşundan bir ay önce, yani yeni bir firka söylentilerinin dilden dile dolaştı̆̆ günlerde tarafinı belli etmiş veya etmek zorunda kalmıştır. Zira muhalifler sürekli olarak reisicumhurun firka reisliğiyle alakasını gündeme getirmişler ve nihayet Gazi, Trabzon'da Halk Firkalılara yaptığı bir konuşmada, tarafsız olamayacağını ve dolayısıyla Halk Fırkasından taraf olduğunu beyan etmiş ve tüm dünyanın şunu bilmesini isteyerek meseleye şu şekilde noktayı koymuştur: Kendisi için bir "taraflılık” vardır. Bu Cumhuriyet taraftarlığı, fikri ve içtimai inkılâp taraftarlığıdır. Halk Fırkasının mefkûresi, esas ilkesi olan bu noktada yeni Türkiye camiasında bir fert dahi dışarıda bulunmamalıdır. Yine ona göre, reisicumhurluk görevi dolayısıyla Halk Fırkasının umumi reisliğini fahri olarak muhafaza etmelidir. Bu şekilde yeni Türk devletinin ve genç Türk Cumhuriyeti’nin güçlenmesine ve sağlamlaşmasına hizmet ettiği kanaatini taşıdığını belirtir (Vakit, 18 Eylül 1924, s. 1; 
Journal of Universal History Studies (JUHIS) • Vol. I • Issue 1 • 2018 • pp. 44-79

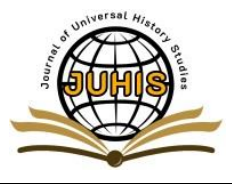

Atatürk'ün Söylev ve Demeçleri II, 1959, s. 189). Trabzon'un ardından Samsun'a geçen Gazi Paşa, burada yaptığ konuşmada kullandığ şu sözlerle Halk Fırkasından yana tavrını teyit etmiş ve muhalif bir firka için ortamın henüz müsait olmadığını söylemiştir (Vakit, 23 Eylül 1924, s. 1):

"Arkadaşlar, bugün idare-i memleket mesuliyeti taşıyan heyet bence mefkîre ve maksat itibariyle bütün millete şamil ve unvan Halk Firkast olan Cumhuriyet Firkasıldr. Bu firkanin esas umdesi memleket ve milletin hakiki selamet ve saadetini temine çalş̧makttr".

Öte yandan bu sıralarda yeni firka lehinde ve aleyhinde yayınlar devam etmiştir. Aynı zamanda yeni firkanın temel politikaları basında yer bulmaya başlamıştır. Buna göre yeni firka; cumhurbaşkanına fesih ve veto hakkı vermemek, bir dereceli seçim taraftarı olmak, bazı sert kanunları tatbik etmemek, belediye başkanlarının seçimle belirlenmesi usulünü getirmek, yenileşmeye doğru yeni adımlar atılmasııı sağlamak, gibi esaslar etrafinda vücuda gelecektir (Tevhid-i Efkâr, 9 Kasım 1924, s. 1; Akşam, 9 Kasım 1924, s. 1).

İstanbul basınından bilhassa Son Telgraf, muhalif hareketin düşüncelerinin kamuoyuna iletilmesinde önemli bir vasita olmuştur. Gazetenin Ankara muhabirine beyanat veren Rauf, Canbolat ve Ahmet Şükrü Beyler muhalefetlerinin temelde neye dayandığını şu şekilde izah etmişlerdir (Son Telgraf, 10 Kasım 1924, s. 1):

"Fırkanın inkssamı muhakkakt. Onlarla beraber kalamazdlk. Çünkü meclis sükût ediyordu. Milletin penah meclisi kurtarmak, mevki-i ihtirama çıkarmak lazımdır. Hakimiyet ne bir kişide ne de hükûmette kalamaz. Memlekete meclis hakim olacakttr. Son kuvvet olan meclisi kurtarmak, yükseltmek vazifemizdir. Daima kulluk edenler, muvafik olanlar meclisi batirtyorlardi".

Türk demokrasi tarihi üzerine ciddi incelemeleri bulunan Karpat da benzer düşünceleri ileri sürmüştür. Ona göre; Terakkiperver Furka temelde, muhalefet kontrolü olmaksızın bütün kuvvetlerin TBMM'de toplanmasının otoriter bir idare yaratacağı fikrine dayanmıştır. Frrka özellikle birkaç kişinin oligarşik gayelerine karşı koyarak ferdi hürriyetleri korumak amacını gütmüşț̈r (Karpat, 1967, s. 45).

TPCF’nin teşekkülüne Mübadele, İmar ve İskân Vekili Refet Bey hakkında 20 Ekim 1924 günü verilen bir soru önergesi vesile olmuştur. Önergede mübadil ve muhacirlerin yerleştirilmesinde görülen yolsuzluk ve beceriksizlikler eleştirilmiş, söz konusu Vekilin verdiği cevaplar meclis tarafindan tatmin edici bulunmamış ve sual istizaha dönüştürülmüş̧ür (Tunçay, 1992, s. 100) Halk Frrkası çevrelerinde ise istizah meselesinin bir bahane olduğu, hakiki maksat ve emelin gizlendiği düşünülmüştür (Benizade Hamdi, 7 Kasım 1924, s. 1).

Aynı günlerde Kazım Karabekir Paşa askerlik görevinden istifa ederek meclise katılmıştr. Bu gelişme mecliste yeni hadiselerin habercisi olarak görülmüştür. Bu arada mebus komutanlar meselesi 
Türk Siyasal Hayatının Vakitsiz Doğan Çocuğu: Terakkiperver Cumhuriyet Fırkası/Ersin MÜEZZINOĞLU

gündeme getirilmiş̧ir. Söz konusu komutanlar harp şartlarında uygun görülen bu iki vazifeden yalnız birini seçmek zorunda bırakılmıştr. Zira barış zamanında yüksek komuta heyetini meydana getiren şahısların aynı zamanda mebus olarak kanun yapma yetkisine sahip bulunması, ordunun yönetimi, idaresi ve düzeniyle bağdaşturlamamıştır. Esasında bu karar apaçık Mustafa Kemal Paşa'nın siyasi bir manevrasıdır. Nitekim onun talebi ile bağllıklarını sunan Fevzi, Fahrettin, İzzettin, Ali Hikmet ve Şükrü Naili Paşalar mebusluktan istifa etmişlerdir. Öte yandan Kazım Karabekir, Ali Fuat, Cevat ve Cafer Tayyar Paşalar ise kumandanlıktan çekilmişlerdir (Cumhuriyet, 1 Kasım 1924, s. 1; Mehmet Asım, 2 Kasım 1924, s. 1). Karabekir Paşa'nın istifa mektubu âdeta bir ültimatom niteliğinde olmuştur (Karaosmanoğlu, 1984, s. 76). Karabekir, bir senelik ordu müfettişliği zamannnda gerek teftişleri neticesinde verdiği raporlarnnın gerekse ordunun güçlenmesi için takdim ettiğ layihalarının dikkate alınmadı̆̆ın gördüğünü, bunun kendisinde üzüntü ve ümitsizliğe yol açtığıı ve bu durumda kendisine düsşen vazifeyi mebusluk stfatıyla yerine getirmeyi düşündüğ̈üü belirterek istifa gerekçesini açıklamıştrr (Vakit, 28 Ekim 1924, s. $1)$.

Ali Fuat Paşa'nın istifasına gelince; aslında Gazi'nin arkadaşlıkları çok eskiye dayanan sınıf arkadaşıyla aralarındaki uçurumu kapatması ve istifasına engel olması zor olmazd. Bunu sağlamak için 30 Ekim 1924'te Konya'dan Ankara'ya dönen Ali Fuat Paşa'yı Çankaya'ya davet etmiştir. Fakat davetle görevli kimseler ona ulaşamamışlardır. Oysa Ali Fuat Paşa, gayet iyi bilinen Saffet Bey'in (Arıkan) evinde bir ziyarettedir. Biri devlet başkanı, diğeri ordu müfettişi iki devlet adamının o günün küçücük Ankara'sında bulaşamamaları oldukça garip ve kuşkuludur. Bu, müfrit Halk Furkalıların daha özelde İsmet Paşa kanadının reisicumhur ile ılımlıların uzlaşmasıı önleme girişimi olarak değerlendirilebilir. Böylece bu çevre amacına ulaşmıştrr. Nitekim Nutuk'ta görüldüğü üzere, Gazi davete icabet edilmemesini düşmanca bir tutum olarak görmüş̧ür (Karaosmanoğlu, 1984, s. 77-80; Zürcher, 2007, s. 72-73). Ali Fuat Paşa istifa yazısında mebusluk görevine başlamayı gerekçe göstermiştir. Ama istifadan önce Fevzi Paşa ile yapttğ görüşmede haberleşmelerinin kontrol edilmesinden, kimlerle münasebet ettiğinin takip edilmesinden şikâyet etmiş, bu ş̧ekilde ordu müfettişi olarak vazifesini sürdüremeyeceğini belirtmiş̧iir. Muhatabından probleminin çözümü noktasında kesin bir destek alamayan Ali Fuat Paşa, çözümü istifa etmekte bulmuştur (Cebesoy, 1960, s. 100-101); Yalnız Ali Fuat Paşa değil, Rauf Bey de mektuplarnın açllmasından sürekli şikâyet etmiş̧ir(Aydemir, 2008, s. 191-192). Bu iki örnek ayrlanlar bakımından da bir kuşku durumunun söz konusu olduğunu göstermektedir.

Fahrettin Altay, muhalif firkanın kurulacağına dair haberlerinin işitildiği günlerde tanık olduğu Ali Fuat Paşa ile Mustafa Kemal Paşa arasındaki bir münakaşadan söz eder. Mustafa Kemal Paşa, kiymet verdiği kadim arkadaşını tekrar kendine çevirmeye çalışır ve yakın arkadaşlarının demokrasi idare tutumunda kendisinden ayrlmağa başlamalarını ve muhalif bir firkada görünmelerini hoş görmediğini söyler. Ali Fuat Paşa ise cevap olarak esasta bir ayrllk bulunmadığını, meclislerin tek partili olmayacağını, Atatürk'ün partiler üstü kalmasıınn arzu edildiğini söyler. Bu sözler üzerine Mustafa Kemal Paşa, Cumhuriyet'in ilanı ile her şeyin bitmediğini, dünya medeniyet âlemine katılabilmek için başka mühim 
Journal of Universal History Studies (JUHIS) • Vol. I • Issue 1 • 2018 • pp. 44-79

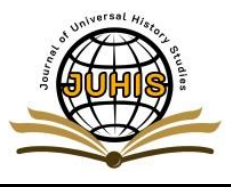

inkılâpların yapılmasının gerekliliğini, bunun için de geçici bir müddet muhalif bir cephe yaratılmamasının zaruri bulunduğunu ifade eder. Ali Fuat Paşa bu defa, kendilerine itimatlarının sarsılmamış olduğunu söylemiş, ancak "muhitinize sokulmaya başlayan bazı türedilerin ifsadatından müteessir olmaktayı", şeklinde cevap vermiştir (Altay, 1970, s. 377-378). Aydemir'in verdiği şu bilgi, Ali Fuat Paşa'nın bu endişesini doğrulamakta, onun ve arkadaşlarının kanaatlerini tam olarak göstermektedir (Aydemir, 2008, s. 189):

“...başta İsmet Paşa ile onun etrafinda toplanan genç, ateşli ve ihtiras sahibi yeni elemanlarm kendilerini bertaraf etmek çabasinda oldukları, Gazi Mustafa Kemal Paşa'nın kendilerine karşı ilgisiz kaldlğ, hatta vefasızlk gösterdiği ve belki de asll şöhretleri bir tarafa iterek diktatörlüğe yöneleceği düşüncesindeydiler”.

Mustafa Kemal Paşa, Nutuk’ta paşaların istifası hadisesini “akim bir komplo" olarak nitelemiştir. Ona göre, Hakkâri bölgesinde Nasturi harekatı yapıldığı sırada İngiltere dahi hükûmete ültimatom vermiş ve bir savaş ihtimali göze alınmış iken, söz konusu komutanlar bu müşkül zamanda, bir yabancı devletin Türkiye'ye saldırabileceği bir zamanda, kendileri de saldırıya girişerek amaçlarına kolaylıkla ulaşabileceklerini hayal etmişler; savaşa hazır bulundurmaya mecbur oldukları orduları başsız bırakıp, vaktiyle sevmediklerini söyledikleri politikayı tercih etmişlerdir(Atatürk, 2010, s. 11341136,1138).

Gelişmeler adım adım muhalif firkanın teşekkülüne doğru yaklaşıldığını göstermiştir. Özellikle 8 Kasım 1924 günü Mecliste yapılan güven oylaması muhaliflerin belirmesine yol açmıştır. Hükûmete 19 mebus itimatsılık göstermiştir. Böylece muhaliflerin ilk imtihanı güven oylamasında gerçekleşmiştir. Müteakiben encümenlerin intihabı muhaliflerin gücünün sınandığı diğer bir gelişme olmuştur. Fakat Kazım Karabekir ile Ali Fuat Paşalar görev devri muamelesinden dolayı mecliste yer alamamışlar ve onlar adına arkadaşları çalışmışlardır. Biraz da bundan dolayı encümen seçimlerinde kayda değer bir başarı elde edememişlerdir. Yalnız muhalifler içerisinde adı geçen Ahmet Şükrü Bey ikinci şube reisliğine seçilmiştir (Cumhuriyet, 3 Kasım 1924, s. 1; Vakit, 3 Kasım 1924, s. 2).

Paşaların bu şekilde komutanlık görevlerini devredinceye kadar meclis çalışmalarından mahrum bırakılmaları planlı bir teşebbüs olarak değerlendirilmiş ve bu yolla gensoru görüşmelerinin sonuçlanmasının amaçlandığı üzerinde durulmuştur. Zira I. Ordu Müfettişliği merkezi Ankara'da olduğundan Kazım Karabekir Paşa’nın görünüşte katılmasına engel bir durum yoktur (Goloğlu, 2007, s 76).

Bütün bu gelişmeler muhaliflerin artık Halk Fırkası çatısı altında barınamayacağını göstermiştir. İktidar firkasından pek çok isim muhaliflerin firkadan ayrılması gerektiğini düşünmüş hatta yolda karşlaştıklarında, "siz hâlâ istifa etmediniz mi? diye söylenmişlerdir (Akşam, 10 Kasım 1924, s. 1). Beklenen istifalar sonunda gelmiştir. İlk etapta Rauf Bey'in de içinde yer aldığı 10 mebus Halk Fırkasından ayrılmıştır. İstifalardan daha çok, burada ortaya konulan gerekçeler Halk Fırkasını rahatsız 
Türk Siyasal Hayatının Vakitsiz Doğan Çocuğu: Terakkiperver Cumhuriyet Fırkası/Ersin MÜEZZINOĞLU

etmiş̧tir. Zira istifa metinlerine göz atıldığında, kimi “muhafaza-i mukaddesat" kavramına vurgu yapmış kimi ise "Halk Firkası azalığından kaydımın terkinini rica eylerim" gibi basit bir ifade kullanmıştr. Bunlar içerisinde Halk Frrkasında en çok rahatsızlığa yol açan İsmail Canbolat'a aittir. Çünkü o sadece, "defterde ismim vardır o ismi siliniz" ifadesini kullanmıştrr (Vakit, 11 Kasım 1924, s. 5; Cumhuriyet, 19 Kasım 1926, s. 1). Tanin gazetesi yazarı Hüseyin Cahit Bey bu durumla ilgili, "son istizahta eleştirilerini srralayan mebuslara öyle tecavüzkârane davranılmıştır ki istifaların daha fazla hürmetli olmasını beklemek fazla olur", tespitini yapmıştr (Hüseyin Cahit 12 Kasım 1924, s. 1).

Aynı günlerde Ali Fuat ve Cafer Tayyar Paşaların devir muameleleri tamamlanmış ve meclise dönmüşlerdir. Artık yeni bir firkanın teşekkülü kaçıılmaz olmuştur. Muhalifler, kuracakları yeni firkanın programı ve esaslanı ile ilgili hummalı bir çalışmaya girişmişlerdir. Toplantılar skkıkla Sabit Bey'in evinde yapılmıştr. Aynı günlerde Halk Frrkası çevrelerinde başlangıçta bir tasfiye konuşulmakta iken, bilahare bundan vazgeçilmiş̧tir. Frrka Katib-i Umumisi Cemil Bey'in belirttiği üzere tasfiyenin kendiliğinden, yani malum bazı kişilerin istifa ve çekilmeleriyle gerçekleşmesinde karar kılınmıştır. Yine Cemil Bey'e göre tasfiye öteden beri gerekliydi ve bu suretle firka daha mütecanis bir şekle girmiş olacaktı (Akşam, 11 Kasım 1924, s. 1). İstifalar peyderpey devam etmiştir (Cumhuriyet, 10 Kasım 1924, s. 1). İstifalar için ortalama 25-30 civarnnda rakamlar telaffuz edilmiş̧ir. Fakat muhalefete yakın gazetelerde bu rakamları çok üstü dillendirilmiştir (Son Telgraf, 10 Kasım 1924, s.1; Son Telgraf, 11 Kasım 1924, s.1).

Halk Frrkası istifalar üzerine birtakım önlemler alma gereksinimi duymuştur. Frrka disiplinini sağlamak amacıyla nizamnameye ilave bazı yeni maddeler konulmuş̧ur. Ayrıca Halk Frrkasının adı değiştirilerek 'Cumhuriyet' ön adı alınmıştır (Cumhuriyet, 11 Kasım 1924, s. 1). Yeni firka ile ilgili ilk duyumlar ve haberler "Cumhuriyet Fırkası" namı altında teşekkül edeceği doğrultusunda olduğu için Halk Furkasindaki bu son değisisillik oldukça dikkat çekicidir (Son Telgraf, 10 Kasım 1924, s. 1). Halk Furkası bir el çabukluğu ile muhaliflerin inhisarnna hiç bırakmak istemediği bu ismi kapmıştır. Bu şekilde firkalarının adııı ellerinden kaçıran muhalifler artık gizliliğe dikkat etme kararı almışlardır. Bir süre sonra ise yeni firkanın "Cezri Cumhuriyet Firkası” adını alacağı öne sürülmüştür (Son Telgraf, 16 Kasım 1924, s. 1). Hüseyin Cahit Bey, CHF'nin isim konusunda bu aceleciliğinde yeni firkanın ismini kapmak gibi bir telaşın gözüktüğünü, rakip firkaların adını kapmak yolundaki bu hareketin çocuk kavgalarına benzediğini, önemli olanın firka ismi değil firka ruhu olduğunu belirtmiştir (Hüseyin Cahit, 12 Kasım 1924, s.1). Ali Fuat Paşa da firkalarına cumhuriyet adını verdiklerini, fakat bilahare Halk Firkasının anlayamadıkları bir sebepten dolayı nizamname değişikliği ile kendisine Cumhuriyet Halk Frrkası adını verdiğini, bunun üzerine tabii olarak Terakkiperver Cumhuriyet Frrkası ismini benimsediklerini söylemişstir (Hayat Tarih Mecmuasi, 1965, s. 89).

TPCF’nin kuruluşuna doğru gidildiği günlerde gerek CHF toplantlarnnda gerekse hükümet yanlısı gazetelerde yeni firkanın önde gelen erkânına karşı tarizler başlamıştır. Özellikle Rauf Bey’e yüklenilmiş̧ir. Zaten daha önce Cumhuriyet'in ilanı hususundaki beyanatı dolayısıyla muaheze edilmiş ve 
Journal of Universal History Studies (JUHIS) • Vol. I • Issue 1 • 2018 • pp. 44-79

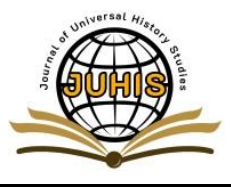

bir hayli hırpalanmıştır. Bu kez bütün felaketlerin başının Mondros Mütarekesi olduğu ve Sultan Vahdettin'in tensibiyle bu mütarekeyi Rauf Bey'in akdettiği dillendirilmiştir (Cumhuriyet, 11 Kasım 1924, s. 1). Ayrıca Rauf ve İsmail Canbolat Beylerin Çerkez oldukları dillendirilmiş onlar ise bunun üzerine "biz onlardan iken Çerkez değildik, halifeci değildik de şimdi mi olduk”' demişlerdir (Son Telgraf, 11 Kasım 1924, s. 1).

Birkaç gün sonra Hüseyin Cahit Bey, Halk Furkasında Rauf Bey ile ilgili söylenen bu sözlerden yola çıkarak kaleme aldığı bir yazıda Rauf Bey örneği üzerinden muhalefete geçtikleri için bu şahıslara karşı yapılan bütün bu suçlamaların ve yıpratma girişimlerinin haksızlığını ortaya koymaya çalışmıştır. Ona göre, Rauf Bey önce meclis reisliği yapmış, ardından başvekillikte görülmüştür. Eski Hamidiye kahramanının "millî mücahededeki" hizmetlerine mükâfat olarak böyle en yüksek mevkilere çıktı̆̆ına hükmedilmiştir. Düne kadar bu şahısların hizmetlerine ve hürmete değer olduklarına CHF kefil olmuştur. Oysa şimdi bütün o teminatın sahte olduğu, Karabekir Paşa ve Ali Fuat Paşa gibilerin birer haris ve garezkâr olduklan ve tüm yaptıklarının bir sandalye kavgasından ibaret bulunduğu söylenmektedir. Hüseyin Cahit Bey'e göre firkacilık ihtiraslarıyla da olsa bir tarihi hakikat bu kadar tahrif edilemez. Mondros Mütarekesi'ni Rauf Bey değil, İzzet Paşa hükûmeti imzalamıştır. Görüşmeler sonunda Amiral Calthorpe, ya bu şartları imzalarsınız yahut İstanbul'a gireriz, demiştir. Rauf Bey de dönmek veya imzalamak şıklarını hükûmete sormuştur. İzzet Paşa hükûmeti müttefiken imzala demiştir. Hüseyin Cahit Bey bu açıklamaların ardından şu tespiti yapmıştır (Hüseyin Cahit, 15 Kasım 1924, s. 1):

"İzet Paşa kabinesinde mütarekeyi imza eden Rauf Bey bugün âdeta hain-i vatan oluyor. Çünkü Halk Fırkasından çıkmıştır. İzzet Paşa kabinesinde mütarekeyi kabul eden ve imza etmesi için emir verenler meyaninda dâhil bulunan Fethi Bey ise bugün Büyük Millet Meclisi Reisi bulunuyor. Çünkü henüz Halk Firkasina mensuptur. Rauf Bey ile beraber Mondros'a giden ve mütarekeyi imza eden Reşat Hikmet Bey'e hin-i vefatında hidemat-ı vataniye tertibinden maaş bağlanıyor. Çünkü vefat ettiği dakikaya kadar Halk Fırkası aleyhinde henüz tenkidatta bulunmamıştı. Bu ne mantıktır, bu ne ölçüdür, bu ne kadar mutaassip firkactlik hissidir".

Hüseyin Cahit Bey bu şekilde muhalif harekete ve onun liderlerine sahip çıkarken, öte taraftan Falih Rıfkı Bey tam aksi düşünceler ortaya koymuştur. Ona bakılırsa İstanbul matbuatınca cumhuriyetçi olarak gösterilen muhalif liderlerin hiçbirinin Cumhuriyet'in ilanında reyi yoktur. Daha yeni, bu kişilerin ağzından cumhuriyetçi kelimesini çıkarmak, otuz iki dişini sökmek kadar zor olmuştur. Falih Rıfkı Bey ayrıca Kazım Karabekir ile 1923’te beraber olduğu Edime seyahatinde, paşanın Selimiye Cami'nin minarelerini göstererek Türk milletini bu minarelerden kışkırtacağız, dediğini hatırlatmış; yine Refet Paşa'nın görünmek, göstermek için iş gördüğünü iddia ederek 1923’te Şişli'de karpuz tüccarlığ bile yaptı̆ğı ilave etmiştir. Yeni firkanın Hürriyet ve İtilaf Fırkasının eşkâliyle doğduğunu öne süren Falih Rıfkı Bey şu tespiti yapmıştır (Falih Rıfkı, 16 Kasım 1924, s. 2):

"Türk milliyetperverliğinin ve inklâbın yeni devlet için vazettiği esaslar tadil etmek 
Türk Siyasal Hayatının Vakitsiz Doğan Çocuğu: Terakkiperver Cumhuriyet Fırkası/Ersin MÜEZZINNOĞLU

isteyenler veya bu esaslarn tadilinde menfaati olanlar, Türkleşmemiş cemaatler, Türklüklerini kaybetmiş kozmopolitler, bazı Beyoğlu unsuru, haşin, dürüst ve kaskanç Ankara'yı zaafa uğratmakta menfaati olanların hepsi karma karışıl, karşımızdadır".

Falih Rıfkı Bey, birkaç gün sonraki bir başka yazısında ise şu görüşleri ortaya koymuştur: Rauf Bey süreçte yalnız Heyet-i Temsiliye azası olarak yer almıştr. Ne savaş yapmış ne de çetelere kumandanlık etmiştir. Ermenistan'da yalnız Kazım Karabekir savaşmamıştır. Halit Paşa da bulunmuştur. Onun adı da zikredilmelidir. Rauf Bey'in Hamidiye kahramanlı̆ı unutulmuyor da Antep ve Urfa gazalarının kahramanları niye hatılanmıyor? Keza Yunan ordusuna ilk kurşunu atan Ali Bey'dir. Bizde savaş yapmayanlar varsa sizde de vardır (Falih Rıfkı, 21 Kasım 1924, s. 2).

\section{Terakkiperver Cumhuriyet Frrkasımı Kuruluşu}

Kuruldu kurulacak denilen bir hazrrlık döneminden sonra yeni firka nihayet 17 Kasım 1924'te resmen kurulmuştur. Trabzon Mebusu Muhtar ile Mersin Mebusu Besim Beyler firkanın nizamnamesi ile kuruluşuna dair beyannameyi Dâhiliye Vekili Recep Bey’e teslim etmişlerdir. Müfrit Halk Frrkallar arasında gösterilen Recep Bey heyeti iyi karşlamış ve "Frrkalar memleket için esastur. Yetişir ki şahsi arzular yerine memleket için çalışsın. Allah mübarek etsin”, demiştir. Emniyet Genel Müdürlüüü 6 numara ile firkanın kuruluş ilmühaberini vermiştir. Söz konusu ilmühaber firkanın gayesini, "hâkimiyeti milliyenin bilakayduşart millette esasına müstenittir" şeklinde tespit etmişstir. Firkanın merkezi Ankara Postahane Sokağı'nda yedi numaralı binadır. Firkanın idare heyetinde ise Ali Fuat Paşa, Rüş̧ü Paşa, Sabit, Rauf, Adnan, Muhtar, Halis Turgut Beyler yer almıştır (Vakit, 18 Kasım 1924, s. 1; Tanin, 18 Kasım 1924, s. 1; Cumhuriyet, 18 Kasım 1924, s.1). Bu noktada TPCF’nin idarecileri bağlamında bir değerlendirme yapılması halinde bu firkanın şöhretinin özellikle kurucu kadrosunun Milli Mücadele'de Mustafa Kemal Paşa ile birlikte bulunmuş en az onun kadar tanınmış asker ve sivil şahsiyetler olmasından ileri geldiği söylenebilir (Ekincikli, 2012, s.152).

Recep Bey'in yeni firkanın kuruluşunu sıcak karşıllaması ve Mustafa Kemal Paşa'nın yeni firka ile ilgili başlangıçtaki olumlu bakışı şöyle değerlendirilmiştir: Önceleri iktidar tarafindan kontrol edilebilir bir "güdümlü” muhalefet oluşturma amacıyla kurulmasına müsaade edilen TPCF, bilahare hükûmet kontrolünden çıması ve iktidar alternatifi hâline gelmesi sonucu istenmeyen bir muhalefet unsuru olmuștur (Uzun, 2002, s. 574).

Meclis dışında kalan İkinci Grubun önde gelenleri de TPCF’ye katılmışlardır. İkinci Grup ile TPCF büyük ölçüde aynı zaruretler sonucu doğmuştur. TPCF programı ile İkinci Grubun programı arasında benzerlikler bu yönüyle şaşrtıcı değildir. Bu nedenle daha önce İkinci Grupta yer alan 18 eski mebus TPCF'ye katılmıştır (Demirel, 2007, s. 600-602). TPCF’nin mebus sayısı hakkında farklı rakamlar verilmekle birlikte genel görüş 29 mebusa sahip olduklarıdır (Çakan, 1999, s. 405). 
Journal of Universal History Studies (JUHIS) • Vol. I • Issue 1 • 2018 • pp. 44-79

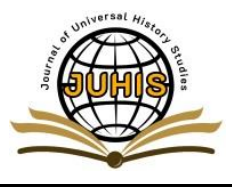

\section{Terakkiperver Cumhuriyet Furkasının Beyannamesi, Programı ve Nizamnamesi}

Şüphesiz yeni firkanın bir çeşit vitrini olarak görülebilecek beyanname, nizamname ve program gibi dokümanları TPCF hakkında yeteri kadar bilgi verebilecek niteliktedir. Beyannamesinde firkanın teşekkül gayesi, siyasi istiklalini kendi azim ve iradesiyle kazanan ve mukadderatını bizzat tayin ve idare etmek olgunluğunu ve kabiliyetini gösteren millete, bu yeni sahada sarsılmadan yürüyebileceği dosdoğru bir yol açmak olarak belirtilmiştir. Yine beyannamede, millî hakîmiyet prensibine vurguda bulunularak bu prensibin fiiliyatta mahdut heyetlerin eline geçmesi ile milleti bu haktan mahrum edebilecek bir istibdat şeklinin meydana gelebileceği tehlikesine dikkat çekilmiştir. Bunun için milletvekillerinin vekâlet haklarını suiistimal etmeyecekleri gerek milletvekillerini gerek icra vekillerini sürekli kontrol altında bulunduracak vasıtalara şiddetle ihtiyaç olduğu belirtilmiştir. Kamuoyu ve basın her ne kadar böyle vasitalar iseler de her zaman etkili ve faydalı olamayabilecekleri ifade edilerek bunlar arasında en etkilisinin aynı kanaati paylaşan mebusların mecliste oluşturacaklan dengeleyici ve kontrol edici gruplar yani firkalar olduğu ifade edilmiştir. Nizamnamede aynca genel hürriyetlerin şiddetle taraftarı olunduğu, şahsi hürriyetlerin her sahada mukaddes görüldüğü, firkanın tefrika demek olmadığını insanların benimseyeceği geniş bir müsaadekarlık takip edileceği, dar firkacılık zihniyetinden kaçınılacağı, başka firkalarla fikirlerde ortaklık söz konusu olursa onlarla da beraber hareket edilebileceği, her türlü irticai hareketlere karşı koymaktan çekinilmeyeceği ortaya konulmuştur. Ayrıca kanunların ihtiyaçlara göre tamamlanacağı ve islah edileceği, firkanın tahakkümlerin aleyhinde bulunmasından ötürü kendi iç işleyişinde de buna imkân verilmeyeceği ne bir kişinin ne de bir grubun tahakküm yolu ile meramlarını kabul etmeyeceği, her karar ve hükmünde yetkili kurulların oy çokluğuna itibar edileceği kaydedilmiştir (Tunaya, 1952, s. 615-616).

Zürcher, TPCF’nin beyanname ve program gibi kaynakları üzerinden öncelikle kişisel dargınlık $\mathrm{m}$ siyasal program $\mathrm{m}$ tartışması yapmış, nihayette kişisel çekişmelerin partinin ortaya çıkışında etkili olduğu görüşüne hak verdiğini söylemiştir. Aynı zamanda parti programının Sabit, İsmail Canbolat ve Ahmet Şükrü Beyler gibi sivrilmiş sivil politikacılar tarafindan yapıldığını ve TPCF'nin bağımsızlık sonrasının muhafazakârları olarak görülebileceğini kaydetmiştir (Zürcher, 2007, s. 135-153).

Yeni firkanın programının ve beyannamesinin ortaya çıkmasından sonra Halk Firkalıların ilk tepkisi yeni firkanın programının kendilerinden farklı olmadığı ve dolayısıyla böyle bir firkaya ihtiyaç bulunmadığı doğrultusunda olmuştur (Akşam, 19 Kasım 1924, s. 1). Terakkiperver Cumhuriyet Firkası üzerine yapılan bazı incelemelerde de bu görüşler ortaya atılmıştır (Sezgin ve Saylan, 1983-1985, s. 2050). İlerde söz edileceği üzere, Mustafa Kemal Paşa da aynı kanaate sahiptir. Öte yandan yeni firka önde gelenleri, bu iddianın yanlışlığını ortaya koymaya çalışmıştır. Yeni firkanın ileri gelenlerinden İsmail Canbolat, firkalarının Halk Fırkasından farkı olmadığı görüşlerine şöyle katılmadığını açıklamıştır (Son Telgraf, 19 Kasim 1924, s. 1):

"Bizim düşündüklerimizi bizim duyduklarımızı duymuş ve düşünmüş olsalardı elbette çekilmeğe lüzum görmezdik. Bir misal olarak meclisi fesih ve veto maddelerini ele alayım: Biz bu hakların reisicumhura verilmesine muhalifiz. Hâlbuki diğer firkanın 
Türk Siyasal Hayatının Vakitsiz Doğan Çocuğu: Terakkiperver Cumhuriyet Fırkası/Ersin MÜEZZINOĞLU

bilhassa nafiz azast son firka içtimaında bu hakların reisicumhura verilmesinde mahzur olmadığın alenen söylemişlerdi. L̇ște bizi ayıran farklardan basit bir misal”".

Ayrıca TPCF'nin mühim erkânından Ali Fuat Cebesoy'da eski ve yeni firka arasında detaylı mukayeseler yapmış aradaki farklan madde madde sıralamıştır (Cebesoy, 1960, s. 114-116).

Belirtilmeli ki TPCF'liler CHF'nin programı olmadığını ileri sürmüşlerdir. Ali Fuat Paşa da bunlardan biridir. Buna karşı Vakit gazetesi yazarı Mehmet Asım, neden partide iken programımız yok deyip program yapalım demediniz. CHF'de bir kusur varsa bu aynı zamanda Ali Fuat Paşa'nın da kusurudur. Ali Fuat Paşa'nın sözleri siyasi edebiyattır, demiştir (Mehmet Asım, 29 Aralık 1924, s. 1). Keza Ahmet Şükrü Bey de ilerde, İzmir Suikastı yargılamalarında görüleceği üzere, CHF’nin siyasi programı olmadığını, sözü edilen umdelerin ise siyasi firka programı olarak kabul edilemeyeceğini söylemiştir (Cumhuriyet, 30 Haziran 1926, s. 2).

TPCF; İstiklal, Son Telgraf, Tanin, Tevhid-i Efkar ve Vatan gibi İstanbul basınının ekseriyetinden destek görmüștür. Bunlardan biri olan Son Telgraf, TPCF'nin programını değerlendirdiği bir yazıda, firka ve siyaset edebiyatımızın eserleri arasında bu programın da bir yeri olacağını belirtmiş, fakat firkanın teşekkülündeki asıl faydanın özellikle iktidar firkasını tenkit ve kontrol edecek olmasında bulunduğunun altını çizmiştir (Son Telgraf, 19 Kasım 1924, s. 1).

Yine Son Telgraf, iki firka arasındaki farkları ise şu şekilde açıklamıştır: Yeni firka hakk-1 hakîmiyet ve hükümraniyetin bilakayduşart kullanılmasını millet meclisinin yetkisi dairesinde görüyor ve bunlardan herhangi birinin yürütme tarafindan kullanılmasına karşıdır. Hatta milletten vekâlet alınmadıkça anayasanın da değiştirilmesine muhaliftir. Oysa Halk Fırkası, veto ve fesih yetkisini yürütmeye vermekte beis görmüyor. Yeni firka şehreminlerin seçimle gelmesini savunuyor. Halk Fırkası ise aksini söylüyor. Yeni firka idari adem-i merkeziyet esasını savunuyor. TPCF demokrasi ve cumhuriyet mefhumu gereği bir dereceli seçimi savunuyor. Halk Furkası her ne kadar yeni firkayla yarışmak için bu doğrultuda bir teklif vermişse de önderleri bunu benimsemiyorlar ve karşı çıkıyorlar. Cumhurbaşkanının seçimden sonra mebusluk sıfatının sone ermesi yeni firkanın programında mevcut olmasına karşın, Halk Fırkası bu hususta farklı düşünüyor (Son Telgraf, 23 Kasım 1924, s.2). Görüldügü üzere Son Telgraf TPCF’ye çok ciddi destek vermiş ve CHF'ye nazaran bu yeni firkanın daha demokratik ve ideal değerlere sahip olduğunu öne çıkarmıştır.

58 maddeden oluşan TPCF programının özellikle dikkat çeken maddeleri şunlardır (Tunaya, 1952, s. 616-618): Türkiye devleti halkın hâkimiyetine dayanan bir cumhuriyettir (Madde 1). Hürriyetperverlik, halkın hâkimiyeti, firkanın temel mesleğidir (Madde 2). Yapılacak kanunlarda halkın ihtiyac, menfaatleri, yönelişleri, asrın gerekleri ve adalet prensipleri hâkim olacaktır (Madde 3). Firka genel hürriyetlere şiddetle taraftardır. Toplumun ihtiyaçlan, istekleri ve toplumsal düzenin korunması endişesi için bu hürriyetlere sınır koymak zaruri olursa ancak Teşkilat-1 Esasiye Kanunu ile bu sınırın konulmasına 
Journal of Universal History Studies (JUHIS) • Vol. I • Issue 1 • 2018 • pp. 44-79

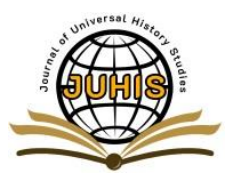

taraftar olunacaktır (Madde 4). Milletten açıkça vekâlet alınmadıkça Teşkilat-1 Esasiye Kanunu değiştirilmeyecektir (Madde 5). Fırka efkâr ve itikadat-1 dinîyeye hürmetkârdır (Madde 6). Mebus seçiminde bir dereceli oy verme usulü kabul edilecek ve her kazanın bir seçim bölgesi olması savunulacaktır (Madde 8). Cumhurbaşkanı seçilen kişinin mebusluk sıfatı, seçilmesinin ardından sona erecektir (Madde 12). Millî birliğin bozulmasına engel olmak için devletin gözetimi devam etmek üzere idari adem-i merkeziyet esası desteklenecektir (Madde 14). Şehreminleri, diğer belediye başkanları gibi seçim usulüne tabi tutulacaktır (Madde 23).

İlk beş maddeye bakıldığında buradaki hususların genel prensipler olduğu ve Halk Firkası tarafindan da benimsendiği anlaşılır. Ancak müteakip maddeler yeni firkayı Halk Fırkasından farklı kılan temel hususiyetleri içerir. Programın eğitimle ilgili maddeleri içeriği yani darüleytamlar, vahdet-i terbiye, amelî eğitimin icrası, ilköğretimin mahalline tevdi gibi konular, İttihat ve Terakkinin iktidar yıllarında yani Ahmet Şükrü Bey'in Nazırlığı döneminde uygulanmaya başlanmıştır. Bu bakımdan TPCF programının özellikle eğitimle ilgili kısmının İttihat ve Terakki programıyla benzerliğinin vurgulanması gerekir (Tunaya, 1952, s. 620).

Frrka ayrıca 63 madde ile bir geçici maddeden oluşan bir nizamname de hazırlamıştır. Furkanın beyanname ve programında görüldüğü üzere burada da millî hâkimiyet prensibinden ve cumhuriyet idaresinin güçlendirilmesinden söz edilmiş, ülkenin gelişme yolunda ilerletilmesinden bahsedilmiştir. Nizamnamenin büyük bir kısmı kongrelere hasredilmiştir. Genel kongre ile vilayet ve kaza kongrelerinin oluşumu, çalışma takvim ve usulleri, görev ve faaliyetlerinden söz edilmiştir (Yeşil, 2002, s. 454-462).

\section{Terakkiperver Cumhuriyet Fırkasının Teşkilatlanması ve Faaliyetleri}

Frrkanın faaliyetlerine geçmeden evvel bir hususu burada belirtmek gerekir. $\mathrm{O}$ da yeni firka kurulur kurulmaz bünyesinde eski nafiz İttihatçıları da barındırması önemli bir etken olsa gerek, hemen İttihat ve Terakki ile ilişkilendirilmeye çalışılmıştır. Şöyle ki TPCF İttihat ve Terakki Furkanın bir istihalesi, diriltilmesi ve tekrar faaliyete başlaması şeklinde görülmüştür (Mehmet Asım, 6 Ekim 1924, s.1). Özellikle Ahmet Şükrü ve İsmail Canbolat Beylerin firkada aktif rol almaları bu iddianın en büyük mesnetlerinden biri olmuştur (Vakit, 19 Kasım 1924, s.1). Yine firkanın kurulduğu ilk günlerde önde gelen İttihatçıların İstanbul' da takip edildikleri ve belli mekânlarda içtimalar yaptıkları ile ilgili haberler basında paylaşılmışır (Akşam, 21 Kasım 1924, s.1; Son Telgraf, 2 Ekim 1924, s. 1). Böyle olmasına karşın iktidar sözcüleri yeni firkayı İttihat ve Terakki Fırkasından ziyade Hürriyet ve İtilaf Fırkasına benzetmişler, kendi firkalarıyla İttihat ve Terakki Fırkası arasında ise aynılıklar bulunduğunu iddia etmişlerdir. Yunus Nadi Bey, firkaların nasıl teşekkül ettiğine de uzun uzadıya yer verdiği yazısında, önce İttihat ve Terakki Partisi ile Hürriyet ve İtilaf Furkasının kuruluşlarını anlatmış, ardından CHF’nin kuruluşundan söz etmiştir. Nihayette Hürriyet ve İtilaf Fırkası ile TPCF’nin bir ihtiyaç saikiyle değil, bir ihtiras sonucu doğduklarını iddia etmiş, CHF'den ayrılan Terakkiperverlerin ise İttihat ve Terakki Partisinden ayrlan hizbi tanzir etmekten masun kalabilmelerini temenni etmiş̦tir (Yunus Nadi, 1 Aralık 1924, s. 1). Aynı doğrultuda Mete Tunçay, CHF'nin tek parti dönemini ele aldığı çalışmasında kişiliklere karşı olma sorunu bir tarafa 1924 
Türk Siyasal Hayatının Vakitsiz Doğan Çocuğu: Terakkiperver Cumhuriyet Fırkası/Ersin MÜEZZINOĞLU

sonlarında Türk siyaset sahnesinde yer alan iki partiden İttihat ve Terakki kalıt ve geleneğine hiç şüphesiz CHF daha yakındı, tespitini yapmıştır (Tunçay, 1992, s. 104). İerde görüleceği üzere CHF’ye yakın bazı isimlerin İttihat ve Terakki Frrkası ile ilgili bu olumlu bakışları İzmir Suikastı teşebbüsünden sonra tam aksi yönde bir değişim gösterecektir (Müezzinoğlu, 2015, s. 155-176).

Yeni firkanın resmen kuruluşu ile birlikte Başvekil İsmet Paşa'dan istifa gelmiştir. Yerine Fethi Bey hükümeti kurmuş̧ur. Muhalefete yakın gazetelerde bu gelişme olumlu karşlanmış hatta İsmet Paşa eleştirilerek başvekil olduğunda kendisine bağlanan ümitlerin zamanla sona erdiği ifade edilmiştir. Fethi Bey'in olumlu karşılanmasında özellikle son açıklamaları ve itidalli tutumunun etkili olduğu ileri sürülmüsștür (Fevzi Lütfi, 22 Kasm 1924, s. 1). Mehmet Asım Bey, muhaliflerin Fethi Bey’e güvenoyu vermesini değerlendirdiği yazısına "Hiddet ve Hayret Ettik mi?" başlğııı atmışıtr. Fethi Bey'in beyannamesinde İsmet Paşa'nın programını devam ettireceğini açıklamasına atıf yaparak, demek ki mesele İsmet Paşa hükûmetinin siyasetiyle değil, şahsiyetiyle ilgilidir, demiştir (Mehmet Asım, 1 Aralık 1924, s. 1).

CHF çevrelerine göre TPCF ilk günlerinde bazı buhranlar yaşamıştr. Buna göre firkada şu üç grup bulunmaktadır. Muhafazakârlarla hocalar, Kazım Karabekir Paşa ve birkaç arkadaşı; Adnan Bey, İsmail Canbolat Bey, Refet Paşa ve birkaç arkadaşı. Rauf Bey ile Ali Fuat Paşa’nın durumu ise net değildir. Bir başka iddiaya göre ise TPCF azası İzmit Mebusu Ahmet Şükrü Bey, bir nedenle firkadan ayrlmak istemiş, onu ikna için Adnan Bey İstanbul'a gönderilmişsir (Cumhuriyet, 25 Kasım 1924, s. 1). Öte yandan TPCF'yi destekleyen gazetelerde bu iddiaların yanlışlı̆̆na değinilmiş̧tir. Buna göre, İ̇mit Mebusu Ahmet Şükrü Bey ve bazı arkadaşlarııın âyan meclisi teşkili taraftarı oldukları, hatta firkanın programı tanzim edilirken bu hususta tartşsma yaşandığı ve neticede aleyhtekilerin ekseriyeti nedeniyle karar alınamadığı gibi duyumlar doğru değildir. Aksine yeni firka intizam içerisinde çalışmaktadır. Hatta TPCF Katib-i Umumisi Ali Fuat Paşa ne programımızda böyle bir kayit ne de bu fikirde bir arkadaş vardır. Kesin olarak yalandir, demiştir (Son Telgraf, 25 Kasım 1924, s. 1). Aynı gazeteye göre firka içerisindeki bütün bu intilaf ve karışıklk söylentileri, Kazım Karabekir Paşa’nın reis seçilmesiyle artmaya başlamıştır. Gerçekte iki meclisli yapıyı daha önce Halk Frrkası da tartışış̧tr. Hatta en çok destekleyenlerden biri de Ahmet (Ağaoğlu) Agayev'tir. Ayrıca şimdi tartışlan âyan meclisi teşkili değil, millet meclisi azasından seçilecek ikinci bir meclis oluşturulmasıdır. Buna benzer konular sadece genel kongrede konuşulabilir (Son Telgraf, 27 Kasim 1924, s. 1).

Yeni firkanın mühim isimlerinden Rauf Bey, TPCF ve mesleği hakkında bir gazeteye verdiği demeçte hak ve hakikat yolunda yürüdüklerine emin olduklarını, uzun sürse de hakkın neticede başarlı olacağına inandı̆ğıı belirtmiş̧iir. Rauf Bey TPCF’nin İttihat ve Terakkinin bir istihalesinden ibaret olup olmadığına dair soruya; ülkedeki vatandaşlardan kim firkalarını programını kabul ederse üye olabileceğini, kabul etmeyenlerin şahıs ve görüşlerine de saygilı olduklarını açılkamıştır(Son Telgraf, 6 Aralık 1924, s. 1). Rauf Bey'in bu açıklamasından bir hafta sonra yine TPCF’nin bir azası, İttihat ve 
Journal of Universal History Studies (JUHIS) • Vol. I • Issue 1 • 2018 • pp. 44-79

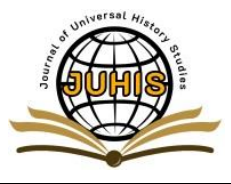

Terakki teşkilatının dağılarak TPCF”ye iltihak ettiğine ilişkin bir soruya, "Fırkamıza her vatandaş girebilir. Tabii olarak bu teşkilattan da yararlanacağız” demiştir (Son Telgraf, 12 Aralık 1924, s. 1).

Bir müddet sonra İstanbul münhal mebuslukları için seçime gidilmiştir. TPCF İstanbul teşkilatını henüz tamamlamadığı için aday göstermemiştir (Son Telgraf, 9 Aralık 1924, s. 1). Ayrıca muhalefete göre müntehib-i saniler çeşitli nedenlerle CHF'ye bağlı olduklarından, aday gösterilmesi firkaya rağbetin azalmasına yol açabilir diye düşünülmüştür. Tahmin edildiği şekilde seçimi $\mathrm{CHF}$ kazanmıştır. Bu bilgilerin verildiği Son Telgraf gazetesinde seçim sonuçları oldukça alaycı ve iğneleyici bir üslupla şöyle değerlendirilmiştir (Son Telgraf, 12 Aralık 1924, s. 1):

"Kazandilar. Kazanacaklardl. Kazanmaları kadar tabii bir şey yoktu. Polisiyle jandarmastyla, hükûmet kuvvetleriyle, kordonlu veya tabancalı memurlartyla müntehib-i sanileriyle yalnız onlar vard. Zaten kaç yıldır biz bu manzaraya alışı̆̆z. Şehremini memurlarina, vali maiyetine, firka mutemetlerine atiyeler verilse 40 gün 40 gece düğün yapsalaryeridir."

$\mathrm{Bu}$ seçimlerin ardından gerginliklere yol açan Bursa seçimlerine gidilmiştir. Burada müstakil olarak seçime giren Nurettin Paşa kazanmıştır. Fakat Halk Furkalılar süresi içerisinde Paşanın askerlik görevinden istifa etmediğini gerekçe göstererek mebusluğunun tasdikini engellemişlerdir. Bu şekilde Nurettin Paşa'nın seçimine itiraz edilmesi ve mazbatasının iptali, muhalifler tarafindan CHP'nin bir müdahalesi olarak yorumlanmıştır. CHP’nin aday çıkarmadığı yinelenen seçimi tekrar Nurettin Paşa önde götürmüştür (Tunaya, 1952, s. 609)'

Teşkilatını tamamlayamadığı için başlangıçta seçimlerde aday göstermeyen TPCF, ilk adaylık gösterimini İzmir seçimlerinde yapmıştır. Burası için, tanınmış İttihatçılardan İzmir eski valisi Rahmi Bey tercih edilmiştir(Son Telgraf, 18 Aralık 1924, s. 1). Seçimlerin kaybedilmesinin ardından yaptığı açıklamada TPCF önde geleni Ahmet Şükrü Bey, Rahmi Bey’in gönülsüz çalıştı̆̆ını ve TPCF adayı ilan edildiği hâlde müstakil olarak seçime girdiğini, gayret gösterseydi kazanabileceğini, ama kararsızlığının böyle olumsuz bir neticenin alınmasına yol açtığını belirtmiştir (Son Telgraf, 30 Aralık 1924, s. 1).

TPCF’nin İstanbul, İzmir ve Trabzon teşkilatına memur edilen Ahmet Şükrü Bey, 1924 Aralık sonlarına doğru teşkilatlanma çalışmalanı ve seçimler hakkında önemli açıklamalarda bulunmuştur. Kırkkilise seçimlerinden halkta memnuniyet verici bir uyanıklık olduğunun anlaşıldığını; Gümüşhane seçimleri için fazla baskı yapıldığının işitildiğini; Urfa ve Kırşehir'de ise seçimlerin kaybedilmesinin bu bölgedeki müntehiplerin çiftlik ve arazi sahipleri olmaları ve hükûmetle daha çok münasebetleri bulunmaları dolayısıyla hükûmetin adayına oy vermezlerse işlerinin yapılmayacağı korkusundan kaynaklandığın belirten Ahmet Şükrü Bey, ahalisi nispeten daha münevver olan şehirlerde seçimin her türlü vasıtalara rağmen daha başarılı gerçekleştiğini ifade etmiştir. Açıklamasında hükümet memurlarının CHF lehine seçimlere tesir etmelerine ve oy güvenliği ile ilgili yanlışlıklara da işaret eden Ahmet Şükrü Bey, muhabirin Halk Fırkasına karşı muvaffak olacağınızı ümit ediyor musunuz? sorusuna şöyle cevap 
Türk Siyasal Hayatının Vakitsiz Doğan Çocuğu: Terakkiperver Cumhuriyet Fırkası/Ersin MÜEZZINOĞLU

vermiştir (Son Telgraf, 23 Aralık 1924, s. 2): “Görüyorsunuz ki Halk Fırkasına karşı bir adem-i memnuniyet ruhu vardır. Ve bu ruh, kendi kendine faaldir. Bir bir kendini gösteriyor"'

Ahmet Şükrü Bey'in yukanda aktarılan bu açiklamaları CHF çevrelerinde rahatsılık yaratmıştır. Özellikle CHF'ye karşı bir memnuniyetsizliğin var olduğunu belirtmesi, Gazeteci-Mebus Yunus Nadi Bey’i köşesinde cevap vermeye sevk etmiştir. Yunus Nadi Bey’e göre, Ahmet Şükrü Bey taahhütname vererek CHF'ye girmiştir. Açıklamaları amiyane birkaç sözden ibaret olup, TPCF ile ilgili yeni bir fikir vermemektedir. Ahmet Şükrü Bey Halk Fırkasına karşı memnuniyetsizliği nerelerde ve nasıl gördüğünü izah etmemiştir. Ahmet Şükrü Bey'in yaptığı demagojidir. (Yunus Nadi, 25 Aralık 1924, s. 1).

Ahmet Şükrü Bey, Yunus Nadi Bey’in yukarıdaki yazısına İstiklal gazetesinden cevap vermiştir. Öncelikle taahhütname konusuna değinerek taahhütname ile mebus olmadığını belirtmiştir. Ardından Ahmet Şükrü Bey yeni firkanın ortaya çıkış gerekçesini açıklamıştır. Buna göre Cihan Harbi milletlerin kendi kaderini kendilerinin belirlemesi gereğini güçlendirmiş ve Türk milleti de buna inanmıştır. İşte bunun için milletin kendi kendini idare etmesini sağlamak ve milleti ilgilendiren konularda bir zümrenin veya bir kişinin tahakkümünü ortadan kaldırmak amacıyla TPCF kurulmuştur. Bu bilginin ardından Ahmet Şükrü Bey Halk Fırkasında ciddi rahatsızlık yaratacak şu sözleri kullanmıştır (Tanin, 28 Aralık 1924, s. 1):

"Son söz olarak bir ricada bulunacağım. İkide bir umdelere sadakat, umdelerle mebus olmak gibi sözler tekrar olunuyor. Mebusluğa esas olan bu umdeler nedir? Bunların sağlam neresi kalmıştır? Madde madde yazarsanı benim gibi bu umdelerin cahili olanları tenvir buyurmuş olursunuz".

Nitekim Yunus Nadi Bey, Ahmet Şükrü Bey’in umdelerle ilgili bu sözlerine hemen karş1lik vermiştir: "Umdeler tatbikat sahasindadirlar ve bütün kuvvet ve şevketleri ile yürüyorlar. Hatta sizin firkanızın tuttuğu yol bile umdelerin mahsulüdür, Şükrü Beyefendi”" (Yunus Nadi, 28 Aralık 1924, s. 2).

Kuruluşun ilk günlerinde TPCF'nin mühim simalarından Mersin Mebusu Besim Bey’in yaptığı şu açıklama, yeni firkanın temkinli hareket ettiğini ve siyaset zeminine ayaklarını sağlam basmak istediğini açıkça göstermiştir (Akşam, 19 Kasım 1924, s. 1):

"Hükûmete beyannamemizi verdik. Artik memleketin menafini daha samimi ve daha serbest bir tarzda müdafaa edeceğiz. Fırkanın teşekkülü memlekette mühim bir hadisedir. Şimdiye kadar teşekkül eden firkaların akbeti malumdur. Biz bu firkaların düş̧їkleri hatalara karışmayacă̆ız. Vaka bir imtihan devresi geçirmekte olduğumuzu biliyoruz. Fakat bu imtihanı kazanmağa çalışacağız."

Bir süre sonra, bu kez TPCF’nin önde gelenlerinden Feridun Fikri Bey, gerçek maksatlarının iktidar mevkini ele geçirmek değil, millet meclisinin hukukunu ve vasi yetkilerini temin etmek, yetki yollarına giden esaslanı hazırlamak, hükûmeti ve işleri gözetim altında bulundurmak olduğunu dolayısıyla 
Journal of Universal History Studies (JUHIS) • Vol. I • Issue 1 • 2018 • pp. 44-79

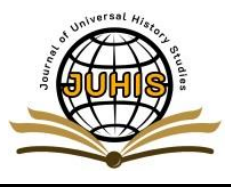

bir zaman için işleri ellerinde tutanlar değil, işleri kontrol edenler vaziyetinde kalacaklarını söylemiştir (Son Telgraf, 28 Aralık 1924, s. 1). Feridun Fikri Bey'in bu beyanını destekler nitelikte bir açıklamayı sonradan Ali Fuat Paşa da yapmıştır. O, Cumhuriyet'in ilanından sonra Atatürk'ün partiler üstü kalacağın düşündüğ̈̈nü, fakat onun ülkede hakiki bir reform ve kalkınma yapacak bir firkanın (Halk Firkası) başında bulunmayı arzuladığını, sonra TBMM'de yalnız Atatürk'ün partisinin olup kimsenin karşısında parti kurmaya cesaret edemediğini, böylece hükûmetin meclis murakabesinden mahrum kaldığını, bu durumun böyle süremeyeceğini ve memlekete son bir hizmet daha etme düşüncesiyle önemli vazifeleri bırakarak ve sirf TBMM'de murakabe vaziyetinde kalmak şartıyla Cumhuriyet Furkasını (TPCF) kurduklarını, meclisten 80 kadar mebus bu partiye gelmek istemişse de hedeflerinin iktidara geçmek değil, aksine murakabede kalmak olduğundan 38 kişiyle yetinildiğini söylemiştir(Hayat Tarih Mecmuası, 1965, s. 89). Bu açıklamalardan anlaşılacağı üzere, yeni firka kendisine yöneltilen "iktidar hırsı" ve "istical" gösterme gibi ithamlan kabul etmemektedir.

Muhalif firka karşısında CHF'nin tereddütlü bir politika takip ettiği görülür. Şöyle ki CHF'den 20 kadar mebus bir dereceli intihabın çoktandır firkalarının amacı olduğunu ileri sürerek kabulü için bir takrir vermişlerdir. Söz konusu takrirde bir dereceli intihap, firkanın halkçılık amacıyla örtüşmesi, hakîmiyet-i milliyenin daha esash tecelli etmesi, medeni ülkelerde ve hukuk kaidelerinde bu usulün kabul edilmiş bulunması nedenleri ile gerekli görülmüştür (Akşam, 20 Kasım 1924, s. 1). Teklifin akıbetine bakıldığında sadece ani bir siyasi manevra olarak sözde kaldığı ve devamının getirilemediği görülür.

Yeni firkanın kurucuları Gazi Mustafa Kemal Paşa ile temasa geçerek hareketlerinin kendisine karşı olmadığını, muhalefetlerinin hükûmete karşı bulunduğunu açıklamışlar, bu husustaki beyanlarını gazetelerde yayınlamışlardır. Aksine Halk Fırkası ileri gelenleri, muhalefetin hükûmete karşı değil, doğrudan kendilerine karşı olduğunu Gazi'ye telkin etmişlerdir. Hakikatte muhalefet İsmet Paşa'ya olduğu kadar Gazi Paşa'ya karşı da doğmuştur. Yeni firka yönetiminde Gazi Paşa'ya karşı olanların varlığı, bu iddiayı doğrulamaktadır (Erer, 1963, s. 27-28).

Gazi Paşa'nın kuruluşu sonrası TPCF’yle ilgili ne düşündüğü, Times gazetesi muhabirine verdiği şu demeçten öğrenilmiştir(Vakit, 12 Aralık 1924, s. 1; Son Telgraf, 11 Aralık 1924, s. 1; Atatürk’ün Söylev ve Demeçleri III, 1961, s. 77-78):

“Terakkiperver Fırkanın programinda mevcut, Halk Fırkasinın umdelerinden hariç ve mevzu-ı münakaşa olmağa değer, esasl bir prensip ve fikir görünmüyor. Teferruata ait görülebilen bazı noktalar erbab-ı ihtisasin her gün yeniden tetkik ve münakaşa edebileceği ve yeni neticelere vasıl olabileceği hususattrr. Veto hakk, hakk-ı fesih, Teşkilat-ı Esasiye Kanunu'nun mevadd-ı mahsusası ile tasrih ve tespit olunmuştur. Efkâr ve itikadat-ı dinîyeye hürmetkâr olmak öteden beri tabii ve umumi bir telakkidir. Bunun aksini düşünmek için sebep yoktur. Hâkimiyetimilliyemiz asla tehlikeye maruz değildir. Bütün millet onun müdrik ve fedakâr muhafizıdır. Bir istibdadın mevcudiyetine dair ima ve telmihler bence kabil-i izah değildir". 
Türk Siyasal Hayatının Vakitsiz Doğan Çocuğu: Terakkiperver Cumhuriyet Fırkası/Ersin MÜEZZINNOĞLU

Aynı demeçte Gazi Paşa yekdiğerini murakabe edecek firkaların varlı̆̆ını hakîmiyet-i milliye ve özelikle Cumhuriyet ile idare edilen bir ülke için normal gördügünü, bu tabii vaziyete karşı kendi durumunun da tabii olmaktan başka bir şey olamayacağını beyan etmiştir. CHF ile manevi bağını muhafaza etmesine karşın, cumhurbaşkanının firkaların üstünde olması esasını kabul ettiğini, ancak görevinin hitamında Halk Fırkasının başında firkalılarla beraber fiilen çalışacağını söylemiştir (Vakit, 12 Aralik 1924, s. 1; Son Telgraf, 11 Aralık 1924, s. 1; Atatürk'ün Söylev ve Demeçleri III, 1961, s. 77-78).

Zürcher, Atatürk'ün 1924'te bir muhalefet partisinin kurulmasına karşı bulunduğunu, aynı zamanda taktik gereği kışkırtmalardan mümkün mertebe kaçınarak ihtiyatlı bir tutum izlediğini, hatta İsmet Paşa'nın görevden alınmasının bu politikanın bir sonucu olduğunu söyler. Yine $O$, tüm bunlarla birlikte Atatürk, uzun vadeli bir hedef olarak çok partili demokrasiyi desteklemesine rağmen, bu ideali, sosyal ve kültürel reformlara göre kesinlikle ikinci sıradaydı, diye görüş belirtir ( Zürcher, 1988, s. 19). Nutuk'ta ise TPCF'ye karşı tamamen olumsuz bir yaklaşım söz konusudur. Gazi'ye göre firkanın programı gizli ellerin mahsulüdür. Cumhuriyet kelimesini telaffuzdan çekinenlerin, Cumhuriyet'i doğduğu gün boğmak isteyenlerin kurdukları firkaya cumhuriyet ve hem de Terakkiperver Cumhuriyet unvanı vermeleri ciddi ve samimi değildir. Fırka muhafazakâr olarak ortaya çıksaydı belki bir anlamı olabilirdi. Fakat bizden daha cumhuriyetçi ve daha fazla terakkiperver olduklarını iddiaya kalkışmaları tabii olarak doğru değildir. Bu tespitlerin ardından Gazi Paşa TPCF’nin 6. Maddesine atıfta asırlarca bunun bayrak yapıldığını ve birçok felaketlere uğranıldığını belirtmiş, "TPCF programı en hain dimağların mahsulüdür. Bu firka memlekette suikastçların ve mürtecilerin tahassüngâhı ve ümid-i istinadı oldu”, demiştir (Atatürk, 2010, s. 1184-1186).

Yine 1924 yllının son günlerinde, İsmet Paşa'ya yapılan bir ziyaret esnasında yeni firkanın mühim simalarından Ali Fuat Paşa ile Adnan Bey Gazi Paşa ile karşılaşmışlar ve Gazi'nin 'Türkiye'de partiler ve parlamento hayatının başlamasından dolayı memnuniyet duyuyorum”, şeklindeki sözlerinden hayli hoşnut kalmışlardır (Cebesoy, 1960, s. 125-126).

Ocak 1925 sonlarına doğru TPCF’nin İstanbul merkezi açılmıştır. Açılışta firkanın İstanbul Kâtibi Vasıf Bey bir konuşma yapmış ve şunları söylemiştir: Ülkede daha önce teşekkül eden firkalar haklı haksız iyi akıbete mazhar olamamışlar, yani görevlerini esaslı bir şekilde tamamlayamamışlardır. $\mathrm{Bu}$ durumun bir değil, çok sayıda nedeni vardır. Bir tanesi, firkaların asıl kuruluş maksadı murakabeden ibarettir. Murakabe olmazsa hürriyet teessüs etmiş olmaz ve hükümran olan kuvvet ve vaziyet mutlakıyet olur. Her şeyin her firkanın üstünde bir vatan vardır. Fırkaların kuruluş amacı da buna hizmet olduğundan birbirlerine karşı mücadelenin bu mukaddes kavramı gözden kaçırmadan fikri ve ilmî bir sahaya yönelmesi gerekir. Hele şahsiyete kesinlikle tenezzül edilmemesi gerektiğine inanmaktayız (Tanin 29 Ocak 1925, s. 1; İkdam, 29 Ocak 1925, s. 1). Vasıf Bey yeni firkanın özellikle murakabe etme yönüyle önemli olduğunu belirtmiş ve esas olanın vatanın menfaatleri olduğuna dikkat çekmiştir.

Belirtilmelidir ki yeni bir firka olması ve teşkilatlanma çalışmalarıı tam olarak 
Journal of Universal History Studies (JUHIS) • Vol. I • Issue 1 • 2018 • pp. 44-79

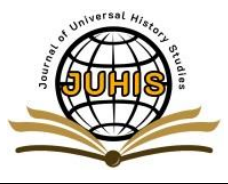

tamamlayamaması gibi nedenlerle girdiği seçimlerde kayda değer bir başarı alamayan TPCF kısa sürede halkta karşllık bulmuştur. Özellikle muhafazakâr doğu, İstanbul ve iskân sorunlarının büyük ölçüde devam ettiği İzmir civarındaki bölgeler firkanın taraftarlarının yoğun bulunduğu yerler olmuştur (Nurgün Koç, 2013, s. 80).

\section{Şeyh Sait İsyanı ve Takrir-i Sükûn Karşısında Terakkiperver Cumhuriyet Fırkası}

Şubat 1925 'te Türkiye'nin doğusunda ortaya çıkan ve elebaşısına atfen Şeyh Sait İsyanı olarak değerlendirilen hadise, Cumhuriyet rejimine ilk ciddi tehlike olarak belirmiş ve genç Türk devletini bir hayli uğraştırdıktan sonra sonuçta askerî tedbirlerle bastırılabilmiştir (Kalafat, 1992; Özdemir, 2002, s. 481-495). İsyanın siyasi neticeleri oldukça önemli olmuştur. Müteakiben anlatılacağı üzere TPCF'nin kapatılmasında önemli bir gerekçe olarak kullanılmıştır. Peki, isyan niçin ve nasıl ortaya çıkmıştır? Hemen belirtilmeli ki hadise tüm yönleriyle aydınlığa kavuşturulmuş değildir. Zira salt dinî yani irtaicai bir hareket mi yoksa elebaşısının etnik kimliği (Kürt) ve hedefleri bağlamında bölgedeki Kürt unsuru üzerinden ayrılıkçı bir hareket mi olduğu, yabancı bir devletin tesirinin bulunup bulunmadığı varsa ne ölçüde olduğu gibi hususlar hâlâ açılığga kavuşturulmamış ${ }^{4}$ ve literatürde üzerinde uzlaşılmış müşterek ve hakim bir görüşe varılamamıştır. İsyanın 1923’te Erzurum'da kurulan Âzadi adlı örgüt tarafindan planlandı̆g ve hazırlandığı ileri sürülmüştür (Özdemir, 2002, s. 495).

TPCF Başkanı Kazım Karabekir Paşa isyan hakkında mecliste yaptığı konuşmada, firkasının de tutumuna tercüman olarak, hükûmetin açıklamasından şark vilayetlerinin bazı yerlerinde sınırlı mütegallibenin dışarıdan teşviklerle ve dini alet ederek halkı tahrik ettiğinin anlaşıldığını, hükûmetin örfi idare ilan etmesinin isabetli olduğunu, dini alet ederek millî bütünlüğü tehlikeye düşürmenin vatana ihanet anlamına geldiğini, bunu yapanların lanet edilmeyi hak ettiklerini söylemiştir. Sonra herhangi bir tehlike karşısında bu vatanın evlatlarının her zaman tek vücut bir kütle hâlinde dikileceğini ve her türlü fedakârlığa hazır bulunduğunu tüm dünyanın bilmesi gerektiğini, hükûmetin hadise hakkındaki açılamasını ve aldığı tedbirleri uygun gördüğünü ifade etmiştir (İkdam, 26 Şubat 1925, s. 1). Bu sözlerden anlaşılacağı üzere muhalif firka da isyanın mahiyeti hususunda hükümetle benzer şeyler söylemiş ve hükûmetin aldığı tedbirleri desteklemiştir. Konuşmaların ardından hükûmet tarafindan Hıyanet-i Vataniye Kanunu'na bir değişiklik teklifi verilmiş ve meclis tarafindan ittifakla kabul edilmiştir. Kanuna konulan yeni madde şöyledir(İkdam, 26 Şubat 1925, s. 1):

"Dini veya mukaddesat-ı dinîyeyi siyasi gayelere esas veya alet ittihaz etmek maksadıyla cemiyetler teşkili memnudur. Bu kabil cemiyetleri teşkil edenler veya cemiyetlere dahil olanlar hain-i vatan addolunur. Dini veya mukaddesat-l dinîyeyi alet ittihaz ederek şekl-i devleti tebdil ve tağyire veya emniyet-i devleti ihlal veya dini veya mukaddesat-ı dinîyeyi

\footnotetext{
${ }^{4}$ Şeyh Sait İsyanı üzerine yaptığı incelemede Koç; isyanın din propagandası öne çıkarılmış bir Kürtçülük cereyanı biçiminde değerlendirilmesinin gerektiğini, hükümetin isyana yönelik sert yaklaşımında genç cumhuriyetin bazı çekincelerinin ağır bastığını ve bunun mazur görülebileceğini, doğru politikanın hadiseye daha 1lımlı bir şekilde yaklaşılarak uzun vadeli adımların atılması olduğunu belirtmiştir (Koç, 2013, p.165)
} 
Türk Siyasal Hayatının Vakitsiz Doğan Çocuğu: Terakkiperver Cumhuriyet Fırkası/Ersin MÜEZZINOĞLU

alet ittihaz ederek her ne suretle olursa olsun ahali arasina fesat ve nifak ilkast için gerek münferiden ve gerek müçtemian kavli veya tahriri veya fili bir şekilde veya nutuk irat veyahut neşriyat icrast suretiyle harekette bulunanlar kezalik hain-i vatan addolunur."

İsyan sürerken bu kez meclis dâhilinde müessif bir hadise gerçekleşmiştir. Ardahan Mebusu Halit Paşa meclis koridorunda Afyon Mebusu Ali Bey'le münakaşa ederken silahla yaralanmıştır. Yaralı Halit Paşa ziyarete gelenlere kendisini vuranın Rize Mebusu Rauf Bey olduğunu söylemiştir. Afyon Mebusu Ali Bey'in yakın arkadaşı Rize Mebusu Rauf Bey’i korumak amacıyla ve meşru savunmadan yararlanmak suretiyle suçu üzerine aldığı iddia edilmiştir (Kalafat, 1992, s. 97). Buna karşın hadiseyle ilgili pek çok iddianın ortaya atıldı̆ıı belirtmek gerekir. Ali Bey'in (Çetinkaya) Halk Frrkasından ayrılan paşalardan söz ederken, paşalar hükûmeti şeklinde bir söz sarf etmesinin bu unvana sahip Halit Paşa'yı rahatsız ettiği ve paşalara hakaret şeklinde algilandığı, hadisenin surf bu yüzden kaynaklandığı iddialar arasındadır (Goloğlu, 2007, s. 107). Öyle ya da böyle Halit Paşa'nın yaralanması mebusların büyük tepkisine yol açmıştr. Özelikle Saruhan Mebusu Reşat Bey'in mebusların kanaatlerini ifade edemediklerini belirten şu sözleri, bu tepkinin açık bir örneği olmuştur (Ahmet Cevdet, 11 Şubat 1925, s. 1):

"Bir zamandan beri meclis muhitinde derebeylik havast esmektedir. Birçok rüfeka hakiki kanaatlerini izhar edemiyorlar. Efendiler! Burast millet meclisidir. Herkes en emin bir surette kanaatlerini izhar edebilirler. Nizamname-i dâhilide bir kayıt vardır ki aza müsellahan meclise giremezler. Bu madde bilaistisna ve bilakayduşart tatbik edilmeli veyahut bir kararla ilga edilmelidir".

Bu sözler CHF’nin müfrit kısmını oldukça rahatsız etmiştir. Tepki ve müdahaleler sonucu Reşat Bey sözlerini tevil etmek suretiyle geri almak durumunda kalmıştır (Ahmet Cevdet, 11 Şubat 1925, s. 1). Halit Paşa ise ancak birkaç gün yaşayabilmiştir. Nihai olarak hadise, muhalifler tarafindan kendilerine karşı bir baskı girişimi olarak görülmüştür.

Şeyh Sait İsyanı TPCF programının malum 6. maddesine dayanılarak TPCF'ye mal edilmiştir. Şeyh Sait İsyanı ile ilgili değerlendirmelere bakıldığında bilhassa hükûmete yakın gazetelerin isyanı önemsediği ve onu ciddi ve tehlikeli bulduğu anlaşllr. Bu kabilden olarak Yakup Kadri "Hesap Günü Gelmiştir" başııkı yazısında CHF hükûmetinin geç kalmakla beraber aldığı sert ve kararlı tedbirlerle şimdiye kadar kaybedilen zamanı telafi ettiğini belirtmiş ve hükûmetten şunu rica etmiş̧ir (Yakup Kadri, 25 Şubat 1925 s. 1):

"Gençte patlak veren irtica hareketine mevzî bir isyan nazartyla bakmasin, irtica tehlikesi ihtimali memleketin her tarafi için ayn derecede vardir. Zira işarat ve emareleri hemen her yerde vuzuh ile meşhut olmaktadir. Dini, belediye intihabatina kadar karıştran ve Büyük Millet Meclisine dinî mücahede için mebus gönderen vilayetlerimiz 
Journal of Universal History Studies (JUHIS) • Vol. I • Issue 1 • 2018 • pp. 44-79

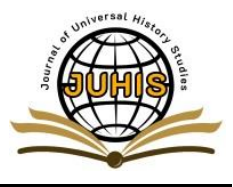

Genç'ten ve Dersim'den çok uzakttr. Osmanlidan Cumhuriyet'e miras kalan gayrimemmunlar sinıfi imparatorluğun haritasının hemen her noktasinda aynı çoğunluktadır."

Karaosmanoğlu, sonradan kaleme aldığı hatıratında eserinde Şeyh Sait İsyanı’nı İsmet Paşa için kendisi katılmamakla birlikte 3. İnönü zaferi olarak telakki edenler olduğunu, Takrir-i Sükûn Kanunu'nun bütün karşı çıkışlara rağmen, meclise kabul ettirerek iktidara gelen, rakip ve muarılarını bir daha baş kaldırmayacak şekilde yenilgiye uğratan İsmet Paşa’nın, 45 yl boyunca edindiği tecrübelerin sşı̆̆ında bu şartlar altında iktidara gelişini kendi hesabına bir bedbahtlık olarak telakki ettiğini, ne kadar haklı, zaruri ve yerinde de olsa fevkalade karar ve kanunlara dayanarak bir çeşit şiddet tedbirleri ile hükûmet etmenin Batı'daki anlamına göre bir devlet ve siyaset adamı için hoş karşılanmadığını yazmıştır. Diğer taraftan yazar, o günlerdeki ateşli devrim heyecanları ve Millî Mücadele rüzgârları içinde dönemin devlet ve hükûmet adamlarına hak verildiğini, hatta onlara destanî bir şekilde bakıldığını da hatırlatmıştır (Karaosmanoğlu, 1984, s. 94).

Falih Rufkı isyanın mahiyetini, 31 Mart Hadisesi'nden beri gelen bir irtica hareketinin ara verdikten sonra devamı şeklinde değerlendirmiștir (Falih Rıfkı 26 Şubat 1925, s. 1). Başka bir yazısında ise isyan hadisesinin İstanbul gazetelerine yüklenemeyeceği ve Kürdistan dağlarında haricî düşmanların gıda almış oldukları bir hareketin memleketin diğer bölgelerindeki fikri münakaşayla bir alakası olamayacağı şeklindeki İstanbul basınının değerlendirmelerine, hariçteki tahrikâtın içteki karışıklık ve kargaşalıklardan kuvvet aldığı şeklinde karşı çıkmıştır (Falih Rıfkı, 27 Şubat 1925, s. 1)

Mart 1925 başlarında gazeteler Başvekil Fethi Bey’ in TPCF mümessillerinin birçok yerde irtica fikrini uyandıracak tahriklerde bulunduğundan şikâyet ederek, bu tahriklerin önünü almak üzere vilayetlerdeki firka teşkilatlarının faaliyetlerine son verilmesini talep ettiğini yazmışlardır. Fethi Bey’in böyle bir talebinin olamayacağı TPCF erkânınca dile getirilmiştir. Ömeğin Hüseyin Avni Bey, Fethi Bey'in böyle bir mütalaada bulunmayacağını düşündüğünü, şayet böyle bir fikir açıkladı ise murakabesiz yönetim zihniyetine bağlllı̆̆ını göstermiş olacağını kaydetmiştir. Yine TPCF'nin İstanbul Kâtib-i Umumisi Kara Vasıf Bey de yaptığı açıklamada böyle bir habere inanmak istemediğini belirtmiştir. Zira daha bir hafta önce CHF toplantısında Terakkiperverlere saldırıldığında, Fethi Bey'in, bazılarının şahsen yaptı̆̆ı bir şeyden bir firkanın sorumlu olamayacağını ve cumhuriyet anlayışında firkaların yer aldığını ve şahsi hatalardan yararlanarak siyasi amaçlarla İstanbul'da örfi idare ilanı mesuliyetini kabul edemeyeceğini söyleyerek tam bir devlet adamı gibi davrandığını hatırlatmıştır. Ardından TPCF’nin taşra şubelerinin irticaya firsat verdiğinin de kesinlikle kabul edilemeyeceğini, zira irtica vesaire sebeplerle çıkan isyan mıntıkasında firkanın ne şubeleri ne de muhabirleri olduğunu, tahriklerin ve isyanın TPCF'nin faaliyette bulunduğu mıntıkaların çok uzaklarında ortaya çıktı̆̆ını söylemiştir (Tanin, 2 Mart 1925, s. 1; Vakit, 2 Mart 1925, s. 2; İkdam, 2 Mart 1925, s. 1).

Böyle bir teklifin vaki olduğu olaya tanık olanlar tarafindan da doğrulanmıştır. Şöyle ki söz konusu buluşmada hazır olan Adnan Bey, Rauf Bey ve Kazım Karabekir Paşa'dan oluşan TPCF heyetine 
Türk Siyasal Hayatının Vakitsiz Doğan Çocuğu: Terakkiperver Cumhuriyet Fırkası/Ersin MÜEZZINOĞLU

Başvekil, kendi elleriyle firkalarını dağıtmaya tebliğe memur edildiğini, firkanın dağtılmaması hâlinde istikbali çok karanlik gördüğünü ve kan döküleceğini söylemiş̧ir. Kazım Karabekir Paşa cevaben, kanun dairesinde firka kurmak elimizdedir. Fakat dağttmak elimizde değildir. Hükûmetsiniz her türlü kuvvetiniz ve vasitanız vardır. Firkayı behemehâl dağıtmak istiyorsanız onu yapmak elinizdedir, demiştir. Bunun üzerine Fethi Bey, sizinle böyle konuştuğumdan müteessirim. Bilirsiniz ki ben her türlü örfi muamelenin karşısındayım. Azınlıkta kalacağımdan korkuyorum, yanııını vermiş̧ir (Cebesoy, 1960, s. 143; Orbay, 2004, s. 498).

Birkaç gün sonra CHF’nin İstanbul Mutemedi Refik İsmail Bey, Terakkiperverlerin mahallelerde dinî kışkırtmalarda bulunduğuna dair daha önce yaptığı bir açıklamayı yinelemiş̧tir. TPCF İstanbul Katib-i Umumisi Kara Vasıf Bey söz konusu açıklamaya şu şekilde cevap vermiştir (Tanin, 4 Mart 1925, s. 1):

"Programimiza, beyanat-l sarihamıza ve Teşkilat-ı Esasiye Kanumina muhalif propaganda ve tahrikâtta bulunanlardan bahsolunuyor. Bu kabil insanlar gazetecilere değil, hükûmete ihbar ile kanunen tecziye ettirmek hem daha doğru hem de memleket menafine muvafiktır. Frrkamız namina böyle bir şeyi mutlak surette reddederim. Şahsen irticai tahrikâtta bulunan varsa ondan malumatım olmadı̆̆ gibi firkamızın da alakası yoktur ve olamaz. Mademki dinî tahrikâtn bir iki aydir devam ettiği iddia ediliyor. $O$ halde hükûmetin bunlardan habendar olmast ve vazife-i kanuniyeye tevessül etmesi lazım değil mi idi? Hâlbuki bugüne kadar Terakkiperverlerin namina böyle muhalif kanun tahrikâttndan bahsolunmadiğı gibi hükümetçe de tecziye edilmiş veya muhakemeye tevdi edilmiş kimse bilmiyorum".

Bütün bu iddiaların gölgesinde Terakkiperverler teşkilatlanma işinde hız kesmemiş ve yeni şubeler açmaya devam edilmiştir. Bu kapsamda halkın talebi üzerine Rumeli, Balat, Beyazıt, Sultanahmet ve Galata şubelerinin açılması için hazırlıklara başlanmıştır (Tanin, 4 Mart 1925, s.1).

Öte yandan isyanla ilgili gelişmelerin seyri Fethi Bey hükûmetinin aldığı tedbirlerin Halk Frrkasını özellikle müfrit diye nitelenen kesimi için pek de yeterli görülmediğini ortaya çıarmıştr. Adı geçen mebuslar hem oldukça hızlı hareket edilmesi hem de sert tedbirlerin alınması taraftarı olmuşlardır. İşte bu ortam içerisinde Gazi Paşa'nın da katıldığı uzun bir grup toplantısı gerçekleş̧irilmiştir. Müfritler ile mutediller birbirlerine ağı itham ve isnatlarda bulunmuşlardır. Hükûmete en ağır tenkitleri Kütahya Mebusu Recep Bey yöneltmiştir. Fethi Bey, Recep Bey'in söz konusu eleştirilerine hayret ettiğini belirterek gerek bu isyanın başlangııı olan Kürt harekâtının gerek Nasturi harekâtının Recep Bey'den devralındığını, son hadisenin sorumlusunun yine Recep Bey olduğunu belirtmiş ve sözlerini şöyle sürdürmüștür: "Yazık ki bugünkü fenalı̆̆, Kürdistan meselesini idaresizliği ile çıkaran bir insan, bugün burada beni tenkit ediyor. Efendiler! Aldığımı tedabir kâfidir. Lüzumsuz şiddetlerle ben elimi kana bulayamam”. Bu sözlerin ardından Fethi Bey’e çoğunluğun itimat edeceği düşünülürken birkaç mebusun 
Journal of Universal History Studies (JUHIS) • Vol. I • Issue 1 • 2018 • pp. 44-79

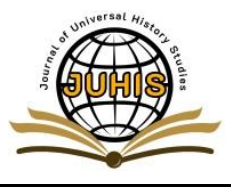

manevrasıyla reisicumhurun da müzakereye iştiraki teklif edilmiştir. Gazi burada yaptığı uzun konuşmada hükûmeti tenkit ederek bir nevi bundan sonrasının rotasını çizen şu sözleri sarf etmiştir: "İnkılâba başlayan inkılâbı tamamlayacaktır'. Gazi Paşa'nın bu duruşu ortaya koymasından sonra sertlik yanlısı grubun verdiği takrir oylanmış ve neticede 60 itimat oyuna karşı 92 ret oyuyla hükûmete itimatsıllık gösterilmiştir. Böylece Fethi Bey azınlıkta kaldığını anlayarak istifasını vermiştir (İkdam, 4 Mart 1925, s. 1; Hakimiyet-i Milliye, 3 Mart 1925, s. 1). Yeni hükûmet beklendiği üzere İsmet Paşa riyasetinde teşkil edilmiştir. Eski kabineden yalnız dört vekil yerini korumuştur. Belirtilmeli ki hükûmetin bu şekilde el değiştirmesi, muhalif firkada istifhamlarla karşılanmış ve vaziyetin açıklığa kavuşturulması arzusu dile getirilmiştir (Hakimiyet-i Milliye, 4 Mart 1925, s. 1).

İsmet Paşa Hükûmeti sıcağı sıcağına doğudaki hadise ile ilgili çok önemli kararlara imza atmıştır. Adından da anlaşılacağı üzere 4 Mart 1925’te Takrir-i Sükûn Kanunu çıkarılmıştır. Her ne kadar kanunun amacı Şeyh Sait İsyanı'na karşı bir tedbir olarak gözükse de tatbikatta kapsamı bir hayli geniş tutulmuştur. Bu cümleden olarak muhalefetin önce susturulmasında, sonra da ortadan kaldırılmasında bir vasita olarak kullanıldığı şeklinde değerlendirmelere yol açmıştır. Bu uygulamaların temel dayanağı kanunun şu hükmü olmuştur (İkdam, 6 Mart 1925, s. 1):

"Iirtica ve isyana ve memleketin nizam-ı içtimaiyesini ve huzur ve sükûnunu ve emniyet ve asayişini ihlale bais bilumum teşkilat ve tahrikât ve teşvikat ve teşebbüsat ve neşriyat hükîmet, reisicumhurun tasdikiyle resen ve idareten mene mezundur. İ̧ bu ef'al erbabinı hükûmet Istiklal Mahkemesi'ne tevdi edebilir"”.

Kanunda yer aldığı üzere hükûmet biri Ankara'da diğeri şarkta görev yapmak üzere iki istiklal mahkemesi teşkil etmiştir (İkdam, 6 Mart 1925, s. 1). Kısa süre sonra Tevhid-i Efkâr, Son Telgraf, Istiklal Gazeteleri ile Aydınlık ve Sebilürreşad dergileri kapatılmıştır (Tanin, 7 Mart 1925, s. 1). Tanin yazan Hüseyin Cahit Bey, Takrir-i Sükûn Yasası'nı ve bununla başlayan muhalefete dönük uygulamalan protesto için aynı gün köşesinde Malta hatıralarını yayınlamaya başlamıștır (Hüseyin Cahit, 7 Mart 1925, s.1). Özellikle zikredilen gazeteler muhalif firkaya gerek kuruluşu döneminde gerekse faaliyetleri esnasında önemli destek vermişlerdir. Böylece TPCF yayın yönüyle dayanağından mahrum kalmıştır. Öte yandan hükûmet askerî anlamda isyanı oldukça sert bir şekilde bastırmıştır.

Falih Rıfkı Bey, devletin isyana karşı bu tutumunu köşesinde şöyle izah etmiştir: Yeni Cumhuriyet, Osmanlı Devleti'nin asi ve isyanlar için bir çeşit budama niteliği taşıyan politikasının yerine, fenalığı tamamen yok etme yolunu tutmuştur. Buna göre genç Cumhuriyet'in islahat sistemi yeni olduğu gibi, tenkil sistemi de yenidir. Cumhuriyet hükûmeti şeyhlerin isyanını basit bir asayiş ve zabıta meselesi olarak görmemiş, bir medeniyet ve tecanüs kavgası olarak telakki etmiştir. Sonuç olarak Türkiye Cumhuriyeti içinde devlet nüfuzu ile hiçbir nüfuzun mücadele edemeyeceği ve Cumhuriyet kuvvetlerine isyan edilemeyeceği gösterilmiştir (Falih Rıfkı, 14 Mayıs 1925, s. 1). Böylece Falih Rıfkı Bey isyanı ele alma ve müdahale etme noktasında eski ve yeni rejimin mukayesesini yapmış, yeni rejimin kendisine yönelen bu ciddi teşebbüse karşı kararlı ve kökünden kararlar aldığını belirtmiştir. 
Türk Siyasal Hayatının Vakitsiz Doğan Çocuğu: Terakkiperver Cumhuriyet Fırkası/Ersin MÜEZZINOĞLU

Vakit gazetesinde Takrir-i Sükûn Kanunu'nun değerlendirildiği bir yazıda memleketin genel vaziyetinin henüz firka hareketlerine müsait olmadığının daha evvel söylenildiği, birkaç ay geçmeden olayların gelişiminin bu tespitin haklıı̆̆ını gösterdiği, bugün kimsenin Genç İsyanı'nı tertip etmiş olan adamların mecliste gerçekleșen ayrılık hareketlerinden kuvvet ve cesaret almadığını iddia edemeyeceği belirtilmiştir (Vakit, 6 Mart 1925, s. 1).

Yine aynı konuda Siirt Mebusu Mahmut Bey Hakimiyet-i Milliye'deki bir yazısında şu değerlendirmeleri yapmıştır: Hükûmetin memlekette izleyeceği yol takrir-i sükûndu. Siyasi, sosyal ve ekonomik açıdan İsmet Paşa, Fethi Bey'in politikasını devam ettirecekti. Fakat eski kabine ile yenisi arasında dâhilî siyaset bakımından gözüken fark esasta değildi. Bu ihtilaf, teferruat ve tatbikata münhasırdı. İsmet Paşa zaten bu hususta, iç siyasette her şeyden önce son hadisenin hızlı ve şiddetle söndürülmesi, memleketin maddeten ve manen fesattan korunması, huzur ve sükûnun muhafazası, her şekilde devlet nüfuzunun güçlendirilmesi için "ser'i müessir-i tedabir-i mahsusasa" kabul edilmesini gerekli görüyoruz, demişti. Mahmut Bey'e göre bütün fark buradaydı. Mecliste ittifaka yakın bir çoğunlukla kabul edilen Takrir-i Sükûn Kanunu bu siyasetin gerektirdiği tedbirler cümlesinden başka bir şey değildi (Mahmut(Soydan), 6 Mart 1925, s. 1).

Mahmut Bey başka bir yazısında muhaliflerin istiklal mücadelesinin o zor günlerinde bulunulmadığı için neden acele edildiğini söylemesine karşı, tehlikeye maruz kalanın devlet değil, inkılâp, yani bedeli sel gibi Türk kanıyla ödenmiş olan Cumhuriyet ve onun yüce prensipleri olduğunu, inkilâp yıkılırsa devletin de yaşayamayacağını, alınan olağanüstü tedbirlerin ve yapılan bütün tertiplerin inkılâbın muhafaza ve müdafaasına yönelik bulunduğunu söylemiştir (Mahmut(Soydan), 15 Mart 1925, s. 1).

"Vaziyetin Tahlili” başlıklı yazısıyla konuya tekrar temas eden Mahmut Bey, isyanın açık ve gizli bütün sorumlularını ve etkenlerini tespit edip, günahlarına ve sorumluluklarına göre tasnif ettikten sonra özellikle isyanın ruhi, içtimai ve siyasi sebeplerinin dikkatle aranıp bulunması, ondan sonra bu sahada yapılacak icraatın kararlaştırılması gerektiğini belirtmiştir. Ayrıca hükûmetin vazifesinin yalnız isyanı bastırmak değil, bundan sonra bu gibi hareketlere zemin ve zaman bırakmamak, o fikirleri herkesin kafasından çıkarmak olduğunu açıklamıştır(Mahmut(Soydan), 17 Mart 1925, s. 1).

Ankara İstiklal Mahkemesi 1925 Mart ayının sonlarında TPCF İstanbul Kâtib-i Umumisi Vasıf Bey'in muhakemesini gerçekleştirmiştir. Burada ona, Ali Fuat Paşa’ya gönderdiği 1 Şubat 1925 tarihli mektupta, Mustafa Kemal Paşa'yı istiyorsanız CHF'ye halifeyi istiyorsanız bizim firkamıza geliniz, deyip demediği sorulmuştur. Vasıf Bey, Kasımpaşa Şubesinden birinin böyle bir propaganda yaptığı ve polis tarafindan sorgulandıktan sonra serbest bırakıldığı bilgisini vermiştir (Cumhuriyet, 27 Mart 1925, s. 1-2; Cumhuriyet, 3 Nisan 1925, s. 1-2).

Aynı günlerde hükûmete yakın bir gazetede İstanbul'un Ömerli kazasından beş kişinin iğfal edildikleri beyanıyla istifalarını verdiği haberi yer almıştır. İstifa yazısında TPCF görevlilerinin kayıt 
Journal of Universal History Studies (JUHIS) • Vol. I • Issue 1 • 2018 • pp. 44-79

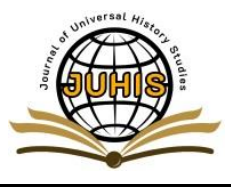

hususunda telkin ettikleri cümleleri taklib-i hükûmet şeklinde gördükleri, programın 6. maddesini dinin vasta edilerek hükûmet aleyhinde tahrikât gibi telakki ettikleri iddiaları bulunmuş̧ur. Vasıf Bey bu kişilerin uzun zaman sonra bazı şeyleri idrak etmelerini dikkat çekici bulduğunu söylemiş̧ir (İkdam, 22 Mart 1925, s. 1).

1925 Nisan ortalarına doğru Ankara İstiklal Mahkemesi TPCF firka merkezi ve şubelerinde aramalar yapılmasına lüzum görmüştür. $\mathrm{Bu}$ gelişme ile firkanın kapatılma süreci de başlatılmıştr. Mahkeme Reisi Ali Bey aramaların gerekçesini, elde bulunan bazı davalarla ilgili safhaların aydınlatılması için Terakkiperver Cumhuriyet Frrkasının İstanbul merkez şubesi ile bu şubeye bağlı diğer şubelerin evrakının incelenmesine lüzum görüldüğü şeklinde açıklamıştır (Cumhuriyet, 14 Nisan 1925, s. 1; Hakimiyet-i Milliye, 14 Nisan 1925, s. 1). Aramalarda firkaya ait bazı defter ve belgelerle şubelere ait mühürlere el konulmuş̧ur. Frrka Kâtibi (Il Başkanı) Vasıf Bey aramalar hakkında, herhalde bir sebebinin olacağını, fakat dürüst hareketlerinden emin olarak neticeyi beklediklerini, araştırmalar sonucunda firkanın meşru ve dürüst durumunun bir kat daha açıklğa kavuşacağını belirtmiş̧tir. Frrkaya atfedilen mevhum gelirler konusuna da değinerek, defterlerin tetkikinden ne alındı̆ğmı, nerelere ve ne miktar sarf edildiğinin anlaşılacağını kaydetmiş̧ir. Ayrıca firkanın kapanmadığın ve kayit muamelesine devam edildiğini sözlerine eklemiștir(Tanin, 14 Nisan 1925, s. 1; İkdam, 15 Nisan 1925, s. 1).

Tanin yazarı Hüseyin Cahit Bey'in TPCF şubelerindeki aramalar için "baskın" tabirini kullanması, tutuklanıp yargılanmasına yol açmıştr. Mahkemede yazarlığı ve geçmişteki kimi hizmetleri göz önünde tutularak Hüseyin Cahit Bey'in cezası hafifletilmiş, Çorum'da mebbet-i sürgün cezasına çarptırlmıştr. İstiklal Mahkemesi Reisi, Cahit Bey'in mahkeme heyetinin suallerine cevap vermediği, eski hayatıı tamamıyla sükutla geçiştirdiğini ve müdafaasının dahi halkı tahrike dayandığıı beyan etmiştir (Hakimiyet-i Milliye, 6 Mayıs 1925, s. 1; Hakimiyet-i Milliye, 8 Mayıs 1925, s. 1). Muhakeme esnasinda mahkeme heyetinin tutumu, yani hükûmetin ve inkılâpların savunulması rolünü üstlenmeleri ve zanllara dava konusuyla pek ilgisi kurulamayan maziye dair birtakım sorular yöneltmeleri, ilerde görüleceği üzere özellikle İzmir Suikastı yarglamalarında da karşlaş̧lan bir durum olmuştur.

Hüseyin Cahit Bey'in mahkûmiyetini değerlendiren Yakup Kadri Bey, onun mahkemede sarf ettiği "şark vilayetlerimizdeki isyan benim neşriyatım yüzünden mi çıkmıştır? sözlerine karşı hayır diyerek, söz konusu yazarın sürekli hükûmet nüfuzunu kırmağa, içcimai ve idari düzeni bozmağa yönelik yayınının böyle bir isyana zemin hazırladığını söylemiştir. Hüseyin Cahit Bey'in ben cumhuriyetçi, laik değil miyim ifadelerine karşı Yakup Kadri Bey, şu durumda cumhuriyetçi olmayan İsmet Paşa mıdır ki Lozan Konferansı'ndan beri bu yazarın sürekli entrikalarnna, taarruzlarına, tecavüzlerine maruz kald, diyerek şunu söylemiş̧tir (Yakup Kadri, 12 Mayıs 1925, s. 1): "Gafillere, son derece demokratik insanlar gibi görünen bu tipler haddizatında, hükümdarlarn etrafinı alan dalkavukların aynıdırlar...Türk milleti pekiyi bilir ki, kendisinden bahsettiğimiz muharrir, bu nevi politikacıların en dessaslarından, en kurnazlarnndan biridir".

Ankara İstiklal Mahkemesi 1925 Mayıs'1 başlarında TPCF ile ilgili "Paşa Mandıralılar" 
Türk Siyasal Hayatının Vakitsiz Doğan Çocuğu: Terakkiperver Cumhuriyet Fırkası/Ersin MÜEZZINOĞLU

davasını görmüştür. Bu bölgede dini alet ederek propaganda yürüten Terakkiperver temsilcisi Kamil Efendi ile aktif azalardan Salih Başo muhakeme edilmiştir (Cumhuriyet, 2 Mayıs 1925, s. 2). Gazetelere göre hadisenin teferruatı şöyledir: TPCF namına üye kaydederken propaganda yaptıkları esnada sözle vatana ihanet etmekle zanlı bulunan Arnavut milletinden Salih Başo ile Paşa Mandıralı köyünde ikamet eden Kamil Efendi, Beykozlu Hüseyin ve Nuri Beylerin yarglanmaları sonucu, Salih Başo hryanet-i vataniyeyi tahrik ve teşvik ettiği için 15 sene küreğe, Kamil Efendi önce idama ardından hafifletici sebeplerden ötürü müebbet kürek cezasına, Resul Efendi’nin tutukluluk süresi dikkate alınarak tahliyesine, Nuri Bey'in ise 5 sene küreğe mahkûm edilmesine karar verilmiştir. Bireysel cezaların yanında mahkemenin aldığı şu karar, TPCF’nin kapatılma kararında temel dayanaklardan birisi olduğu için oldukça önemlidir (Cumhuriyet, 4 Mayıs 1925, s. 3; Hakimiyet-i Milliye, 4 Mayıs 1925, s. 1; Vakit, 4 Mayis 1925, s. 1-2):

"Siyasi bir firka namina icra edilen propagandalarin dini ve mukaddesat- diniyeyi amal ve mekastd- siyasiyeye alet mahiyetini aldığı sabit olması hasebiyle mezkûr firkanin vazı hazırı ve tarz-l faaliyeti hakkanda hükûmetin nazar-ı dikkatinin celbi zımninda müddei-i umumiliğe tebligatta bulunulmasina müttefikan karar verildi".

Öte yandan 4 Mart 1925 tarihli kanuna dayanılarak teşkil edilen Şark İstiklal Mahkemesi de TPCF Urfa Siverek Kâtibi Fethi Bey'in muhakemesini ${ }^{5}$ gerçekleş̧irmiştir. Neticede bu kişi, Hiyanet-i Vataniye Kanunu'na ek olarak kabul edilen kanun maddesi gereği, dini siyasete alet ettiğinin anlaşıldığı gerekçesi ile üç sene kalebentliğe mahkûm edilmiştir. Bundan başka mahkeme Takrir-i Sükûn Kanunu'nun yayınlanmasından sonra programlarnın 6. maddesindeki kayda nazaran devam ve bekası vatana ihanet suçu teşkil eden Terakkiperver Firka ${ }^{6}$ şubelerinin, Hiyanet-i Vataniye Kanunu'nun birinci maddesi ile Takrir-i Sükun Kanunu'nun birinci fikrası ve Cemiyetler Kanunun üçüncü maddesi hükmüne uygun olarak meşru kanuni engellemeye binaen kapatılmasına karar vermiş̧tir (Cumhuriyet, 20 Mayıs 1925 s. 1; Vakit, 20 Mayss 1925; İkdam, 20 Mayıs 1925, s. 1-2).

İstiklal Mahkemelerinde yukarıdaki davalarn görüldüğ̈ ve firkayla ilgili mühim kararlar alındığ esnada TPCF teşkilatlanma çalışmalarını sürdürmüştür. Bu çerçevede 14 Mayıs 1925’te firkanın Cağaloğlu'ndaki merkezinde İstanbul Vilayet Kongresi gerçekleştirilmiş̧iir. Kongreye 9 şubeden delegeler katılmıştr. Frrka Katibi Vasıf Bey kısa bir nutuk irat ederek kongreyi açmıştrr. Vasıf Bey konuşmasında bu ilk vilayet kongresinden memnuniyetini dile getirmiş ve genel kongreye yararlı esaslar hazrlamak maksadıyla kongrenin yapıldığmı belirtmiş̧tir. Sözlerini ise şarktaki hadiseden dolayı hükûmete şu destekle bitirmiştir(Ikdam, 15 Mayıs 1925, s. 1):

“Vatanimızın şark mintikasinda vukua getirilen iffirâkcuyâne ve irticâ'-kâr-âne kyyam-ı hainanenin seri ve kati tedabir ile tenkil ve teskininde hükûmetin ibraz ettiği kudreti ve

\footnotetext{
${ }^{5}$ Fethi Beyin sorgulanması ve yargılanması ile ilgili detaylı bir bilgi için bkz. (Yeşil, 2015, ss. 711-744).

${ }^{6}$ Kararda daha evvel de örnekleri görüldüğü üzere partinin adındaki cumhuriyet lafzının kullanılmadığı dikkat çeker.
} 
Journal of Universal History Studies (JUHIS) • Vol. I • Issue 1 • 2018 • pp. 44-79

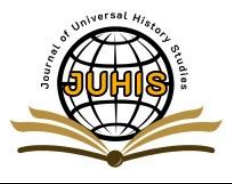

ihraz eylediği muvaffakiyeti vahdet-i milliye ve vataniyemiz için parlak ve kuvvetli bir zimam olarak şükran ile yâd ederim”.

Vasıf Bey'in konuşmasının ardından yeni idare heyetine Cafer Tayyar Paşa, Abidin Bey, Kamil Efendi yeniden; Hüseyin Avni, İsmail Hakkı, Hami Hafim, Doktor Nafiz Beyler ise ibkaen seçildiler. Bu arada vilayet kongresi 15 gün devam etmiştir (İkdam, 15 Mayıs 1925, s. 1).

TPCF Kongresi'ni değerlendiren Vakit’ten Mehmet Asım Bey'e göre, mahkemede hesap veren bir partinin bu girişimi mevsimsizdir. Urfa Siverek mutemetlerinin yargılanmasını beklemeleri gerekir. Erkânı mahkeme kapılarında nöbet bekleyen bir firka rüesasının halk ile temastan içtinap etmemesinde hakikaten cesaret vardır. Ancak, bu cesarete küstahlık denilebilir. Böyle bir firka ancak fesih kararı vermek için toplanabilir. İnkılâp firkaları tabii olan düşmandan korkmazlar, açı cephedir. Asıl tehlike, kendi fikir prensiplerine fazla sadık görünerek bu prensiplere kızıl düşman olan gruplara dayanan bencil, ikbale düşkünlerdir. İktidar firkası, mefkûresine dost olmayanların fesatlarına artık izin veremez. Bu nedenle dostlarımıza tavsiye ederiz: "Toplanacak iseniz dağılmak için toplanınız." (Mehmet Asım, 19 Mayıs 1925, s. 2).

Bir süre sonra Adliye Vekili Mahmut Esat Bey, TPCF hakkında önemli açıklamalarda bulunmuştur. Ona göre, Türkiye Cumhuriyeti’nde efendi olarak yaşamak hakkı Türklere ve Türk olanlara aittir. Dost da düşman da bunu böyle bilmelidir. Geriye doğru muhalefete, entrikacı muhaliflere, firkacılara hiçbir zaman hak tanınamazdı ve bunların akıbetleri hüsran olurdu. Türk inkılâbı geriye doğru geçit veren köprüleri yıkarak ilerlemektedir. Köprüde korkunç kanlı uçurumlar vardır. Gözlerini hâlâ gerilerde gezdirenler ve gerilere ümit bağlayanlar cezalarını çekmişler, bundan sonra da çekmeye devam edeceklerdir (Vakit, 2 Haziran 1925, s. 1). Adliye Vekilinin bu sert sözleri CHF hükûmetinin muhalif firkaya karşı duruşunu ve takınacağı tutumu açıkça göstermiştir. Görüleceği üzere bunun tezahürlerinin ortaya çıkışı da çok gecikmemiştir.

\section{Terakkiperver Cumhuriyet Fırkası'nın Kapatılması}

Şark İstiklal Mahkemesi'nin TPCF'nin doğudaki şubelerini kapatması, aslında daha genel ve köklü bir karar için hükûmetin eline önemli koz vermiştir. Iş̧e Ankara İstiklal Mahkemesinin hükûmetin dikkatini çekişi, Şark İstiklal Mahkemesinin mahkûmiyet kararı ve mıntıkasındaki TPCF şubelerini kapatması, TPCF'nin temelli kapatılmasında hükûmetin temel dayanaklanı olmuştur. 3 Haziran 1925 tarihli toplantısında Hükümet TPCF’nin kapatılmasını kararlaştırmışır. Söz konusu karar, yukarıdaki hususlarla birlikte TPCF programindaki 6. maddenin, dinin siyasete ve irticaya alet edilmesinde bir vasita olarak kullanıldığı ve bunun mahzurlarının son hadisede görüldüğü tezlerine dayandırılmıştır (Vakit, 5 Haziran 1926, s. 1-2).

Oysa Aydemir'in değenlendimesinden anlaşlacağı üzere TPCF'lilerin isyanla yakından uzaktan ilgisini gösteren hiçbir iz bulunamamıştır. Ama TPCF karşıtları, 'efkâr ve itikadat-ı diniyeye hürmetkârdır' lafzının bir irtica hareketi olan Şeyh Sait isyanını körüklediğine inanmışlardır. Hâlbuki zaten anayasaya 
Türk Siyasal Hayatının Vakitsiz Doğan Çocuğu: Terakkiperver Cumhuriyet Fırkası/Ersin MÜEZZINOĞLU

göre de devlet bir İslam devletidir. Yani dini İslam'dır. Bu duruma göre, firkanın programına dini fikir ve inançlara saygı göstereceğine dair bir madde koyması yadırganmayabilir (Aydemir, 2008, s. 206).

Cumhuriyetin ilk muhalif firkasııın bu şekilde kapatılmasının nasıl karşılandığına bakıldığında; Takrir-i Sükûn Kanunu ile muhalefete destek veren bazı gazetelerin kapatılmış olması ve bu kararın diğer gazeteler üzerinde bir çeşit tazyik yaratması nedeniyle yalnız CHF yanlısı basın öne çıkmış, onlar da tabi olarak bu kararı lüzumlu ve olumlu karşılamışlardır. Falih Rıfkı Bey kapatma kararnna değindiği yazısında, siyasi bir firkayı kapatmanın çağdaş bir Cumhuriyet yönetimi için nazik bir mesele olduğunu, İsmet Paşa’nın şimdiye kadar sabır ve tahammül göstermesine meselenin işte bu nezaketinin sebebiyet verdiğini, muhalif firkanın hangi nedenlerle teşekkül ettiğinin ve inkilâp firkasını yıkmak isteyen zihniyetin nasıl tehlikeli akıbetlere doğru yürüdüğünün daha ilk günden itibaren Halk Frrkasının meçhulü olmadığın, buna rağmen hükûmetin müteyakkız davrandı̆ğıı ve muhalefete geçen arkadaşlarıı uyardı̆̆ııı, yine İsmet Paşa’nın iki ay beklediğini yazmıştr. Yazar ithamnamenin ağır olmakla birlikte, Şark İstiklal Mahkemesi, Ankara İstiklal Mahkemesi ve teşkilat-1 mülkiye olmak üzere üç kaynağa istinat ettiğini belirtmiştir. Bu sözlerin ardından kararnamenin içeriğine temas ederek sed kararnın işlenen suçun derecesine göre kâfi bir ceza görülemeyeceğini, fakat halka rehberlik taslayan bazı zatların siyasi terbiyelerini değiştirmek için yeterli bir ders olursa bundan memnun kalacakların belirtmiştir. Falih Rufkı'ya göre, tahrikât ve ifsadatın vücuda getirdiği kanlı faciaya rağmen, sorumlular yalnız bir iki gazete ile ticaretlerinin bir kısmından ve bir firka ise faaliyette bulunmak hakkından mahrum kalmıştr. Son olarak Falih Rıfkı Bey şu tespiti yapmıştr (Falih Rıfkı, 5 Haziran 1925. s. 1):

"Hiçbir inklâp hükûmeti kendini uçurumun kenarnna kadar sürükleyip götüren inklâp düssmanlarnna karşı, ne iki seneden beri olduğu gibi bilakayduşart hürrivet vermek, ne de şimdi olduğu gibi ceza vermek hususunda CHF'nin hükûmeti kadar müsamahakâr olmamuştir. Bu sed karan darbe değil, dostane bir tembihtir ve bu şiddetsizlik inklâp mevki-i iktidarinin zaafina değil, kuvvetine delalet eder. Cumhurivet hudutlar içinde bu kuvvetin bir daha tecrübesine teşebbüs edecek kadar gafil insanlar kalmamış olduğuna inanmak isteriz".

Kapatilma kararı Cumhuriyet gazetesinde, "Heyet-i Vekilenin Muhak Bir Karan, Terakkiperver Cumhuriyet Furkası Şubâtının Seddi” başlığıla verilmiştir. Yazıda karara atfen firka üyelerinin irticai tahriklerde bulunduğunun sabit görüldüğ̈̈ ve bütün şubelerin kapatılmasina karar verildiği, zaten Ankara İstiklal Mahkemesinin firkanın vaziyeti hakkında hükûmetin dikkatini çektiği, yapılan muhakemede TPCF’nin birtakım azasının dini siyasete alet edip irticai tahriklerde bulunduğunun anlaşıldığı, yine Şark İstiklal Mahkemesinin aynı nedenle kendi bölgesindeki şubeleri kapattı̆ı hatıllatılmış ve "zuhuru, zaten bidat-1 tasannu olan bir firkanın zimamdarlanı, hiç olmazsa bu sahte teşekkülü kendi kendilerine kapatı dağtmak izzetini bile gösteremediler, hülasa fena başladılar ve fena bittiler", denilmiş̧tir (Cumhuriyet, 5 Haziran 1925, s. 1). 
Journal of Universal History Studies (JUHIS) • Vol. I • Issue 1 • 2018 • pp. 44-79

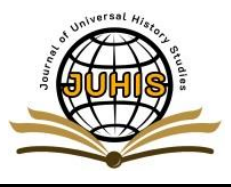

Hakimiyet-i Milliye'den Siirt Mebusu Mahmut Bey’in kaleme aldığı, "Sükût-ı Hayal” başlıklı yazıda, "mevki-i iktidar hırsı, bu firka rüesasının basiretini bağlamıștı" tespiti yapılmış, yeni firkanın bir an önce iktidara sahip olmak gayesiyle her vasıtayı meşru gören bir zihniyetle hareket ettiği belirtilmiştir. Zira Cumhuriyet kanunlarından, inkılâbın ülkede sağladığı hürriyetlerden istifade edilerek yine Cumhuriyet ve inkılâbın aleyhine bir suikast tertip edilmiş ve din tahrik vasıtası olarak kullanılmıştır. Bu durumun ömekleri Osmanlı tarihinde de mevcuttur. Bu noktada Falih Rıfkı'nın, bir taraftan şeriat tahrikâtı, diğer taraftan inkılâp iktidarını zayıf ve müdafaasız gösteren telkinler olmasaydı daha iki sene evvel düşman ordularını Akdeniz'de boğan kuvvete karşı birkaç şeyh, birtakım serserilerle beraber böyle bir hareket cüretinde bulunurlar mı idi? sözü hatırlatılmıştır. Yazının devamında, İstiklal Mahkemelerinde cereyan eden yarglamaların safahatını öğrenenlerin zaten firka hakkında mahkûmiyet kararı verdiği, hükûmetin son kararnamesinin ise vicdanların verdiği bu hükmü, resmî ve kanuni şekle koymak olduğu öne sürülmüş̧ür (Mahmut(Soydan), 8 Haziran 1925, s. 1).

9 Haziran 1925 tarihli İkdam gazetesinde Halk Firkasının İstanbul Başmutemet Vekili İsmail Refik Bey'in açıklamaları yer almıştır. İsmail Refik Bey, TPCF kurulurken İstanbul'un belli semtlerinde tahrikât yapıldığını ve özellikle halkın aşağı tabakasının ilmen fakir olduğu yerlerde söz konusu teşebbüsün hüküm sürdüğünü ve TPCF temsilcilerinin halkı din esası üzerine iğfal ederek firkaya üye yapmaya çalıştı̆ı̆ı, firka yönetimi yalanlasa da aslında bundan haberdar olduklarını iddia etmiştir. Hatta onlar sözlü olarak tahrikât yapılması noktasında emir de vermişlerdir. Sözün burasında 31 Mart Hadisesi’ne atıf yapan İsmail Refik Bey, “TPCF’nin hin-i teşekkülünde İstanbul'da gördüğümüz âraz aşağı yukarı 31 Mart Vakası'nı hatırlatıyordu. Aynı softa tahrikâtı vardı. Şu farkla ki Volkan' in yerine aynı mahiyette ve tesir-i nüfuzu ondan pek çok şamil başka bir iki gazete kaim olmuştu”, demiştir. Sözlerinin devamında, bunlara rağmen CHF yöneticilerinin müteyakkız davrandıklan ve bilhassa İsmet Paşa'nın tedavi dolayısıyla İstanbul'da bulunmasının, vukuatı daha yakından görmesine imkân tanıdığını hatırlatan İsmail Refik Bey, Takrir-i Sükûn Kanunu'nun kabulü, İstiklal Mahkemelerinin teşkili ve tesiri ile gösterilen uyanıklığın ülkenin büyük bir beladan hafif şekilde kurtarılmasını sağladığını ifade etmiştir. Son olarak Mutemet Vekili firkalarına gelmek isteyen TPCF üyelerini kabul etmeyeceklerini de sözlerine eklemiştir (İkdam, 9 Haziran 1925, s. 2).

TPCF’nin kapatılması ${ }^{7}$ ve firkanın Türk siyasal hayatındaki yeri konusunda literatürde oldukça farklı görüşler bulunmaktadır. Aydemir bu konuda her ihtilalin vakti gelince kendi çocuklarını yemesinin kaçınılmaz bir kanun olduğu tespitini yapmıştır (Aydemir, 2008, s. 192). Ayrıca Son Telgraf gazetesinin

\footnotetext{
${ }^{7}$ Yeşil, TPCF’nin kapatılmasını birçok nedene bağlar ve bunları şu şekilde maddeler halinde sıralar: TPCF'nin siyasi karakteri (Halk Fırkası ile arasında temelde siyasi görüş farkı olmamasına rağmen teferruattaki farklar nedeniyle CHF'ye ciddi rakip olması). Fırka kurucuları arasında yer alan Millî Mücadele'nin önde gelen şahsiyetlerinin toplum nezdindeki itibarı. TPCF'nin kısa sürede tabanda yerleşmeye başlaması. TPCF'nin sergilediği muhalefet tavrı ve iktidar ilişkilerinin kalıcı ve köklü bir parti imajı yaratması. İstiklal Mahkemesi kararlarına rağmen TPCF'nin yeniden yapılanma çalışmaları kapsamında İstanbul il kongresini gerçekleştirmesi. Bunların dışında asıl olarak TPCF’yi iktidar gözünde tehlikeli kılan sebep kurucularının ekseriyetinin asker kökenli oluşu (Yeşil, 2002, s. 431-433).
} 
Türk Siyasal Hayatının Vakitsiz Doğan Çocuğu: Terakkiperver Cumhuriyet Fırkası/Ersin MÜEZZINOĞLU

TPCF’yi hürriyetsizliğin ve sstırabın doğurduğu çocuk olarak adlandırmasına karşı çıkan Aydemir, böyle bir nitelemenin yanlş̧ olduğunu, "vakitsiz ve yaşama kabiliyeti olmayan çocuk" demenin daha doğru olacağını söylemiştir (Aydemir, s. 201).

Ateş' in TPCF'yi konu edindiği incelemesine göre, ilerde Serbest Cumhuriyet Furkası örneğinde görüleceği üzere TPCF yöneticileri ve kurulları esneklik göstermemişlerdir. Gazi Paşa'nın beyanları ortada iken ve Şeyh Sait İsyanı'nın çıkmasından sonra kendi elleriyle firkalarıı kapatmaları telkin ve teklif edilmiş iken, bunu reddetmişlerdir. Frrka etrafinda kopan tartışma yeni kurulan bir devlette neyin nasil olması gerektiği yolundaki kavganın dramatik bir görünümüdür. Yüceer, Gazi Paşa’nın tasarladığı inkılâpların hepsini gerçekleştiremediğine ve milleti yeniden yapılandırma sürecinin tamamlanması için biraz daha zamana ihtiyaç duyduğuna atıfta bulunmuş bunun için iktidarın el değiş̧irmemesi gerektiğine inanıldığı dahası inkılâp karş̧tlarının muhalif firka etrafinda toplanıp çok daha etkin ve tehlikeli olabileceği düşüncelerinin TPCF'nin kapatılmasında temel etken olduğunu belirtmiş̧ir (Ateş, 1998, s. 324-325). Sezgin ve Saylan'a göre; TPCF'nin gerçek anlamda bir alternatif olmadığ, kişisel çekişmelerin ve iktidar mücadelesinin bir sonucu olduğu, belli bir toplumsal tabana bağlı olarak belirgin ve farklı bir ideolojisinin yokluğu TPCF’nin ömrünün kısalı̆gnda birinci derece etkili olmuştur (Sezgin, 1983, s. 2050-2051).

Tevetoğlu'na göre yeni Türk devletinin ilk muhalefet firkasına karşı koparlan firtına aslında o zamanın havasının bir sonucudur. Bunu Takrir-i Sükûn Kanununu çkaran ve TPCF’nin kapatılması esnasında başvekil bulunan İsmet Paşa'nın uygulamalarından ve söylemlerinden de anlamak mümkündür. Bir defa İsmet Paşa itham edilen ve firkaları kapatılan arkadaşlarının gönlünü alarak yeniden CHF'ye dönmelerini sağlamıştr. Ayrıca onun şu sözleri meselenin siyasi olduğuna açık bir delildir: TPCF programında yer alan 6. madde, büyük reformlar ve inklâplar yoluna girmiş olan Atatürk idaresi ve CHP iktidarnna karşı, muhafazakâr bir zihniyetin ifadesi gibi görülebilirdi. Aslında bu iddia her büyük reform karşısında, tabii ve meşru olan muhafazakâr akımları temsil eden masum bir iddia olarak görülebilecekse de TPCF hiçbir zaman muhafazakâr cereyanı temsil ettiğini söylememiştir. Şu kaydedilmelidir ki, Terakkiperverlerin başında bulunanlardan büyük kısmı, mazileri ve zihniyetleri bakımından ileri fikirli ve sslahatçıydılar. Frrka, siyasetten çekildikten sonra da temiz ve vatanperver duygularla her alanda memlekete hizmet etmeye devam etmişlerdir (Fethi Tevetoğlu, 1986, s. 41-46) Falih Rıfkı Atay sonradan kaleme aldığı anılarında TPCF’nin kuruluşunu şahsi kıskançık, rekabet ve geçimsizlikler gibi basit sebeplere indirgemenin çok üstünkörü bir bakış olacağını belirtmiş ve TPCF’nin ciddi ve büyük bir hareket ${ }^{8}$ olup gerek halk gerekse o devrin aydınları arasındaki karşlığının devrin ideolojisinin karşılığından çok daha esaslı olduğu tespitini yapmıştır (Atay, 1984, s. 395-396). Ekincikli, TPCF’nın

\footnotetext{
${ }^{8}$ TPCF üzerine yapılan bir incelemede benzer görüşler paylaşılmıştır. Buna göre TPCF, dönemin tek partili yönetim sisteminde, iktidar elitlerinin politik uygulama ve gelişmelerini algılayış farklıllklarının yol açtığı bir ayrışma sonucunda ortaya çıkmıştır. Sınıfsal çıkarların çatı̧̧ması nedeniyle ortaya çıkan bir siyasi hareket olmamakla birlikte TPCF'yi iktidarın ekonomik icraatları ve sosyolojik tasavvurları nedeniyle bir alternatif olarak benimseyen geniş kitleleri bulunmaktadır (Babaoğlu, 2012, s. 64-65).
} 
Journal of Universal History Studies (JUHIS) • Vol. I • Issue 1 • 2018 • pp. 44-79

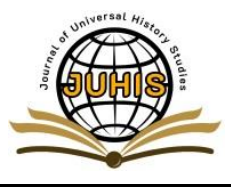

kuruluş aşamasında atılan her siyasi adımın demokrasi kültürünün Türkiye'de gelişmesi açısından ömek alınacak bir seviyede ve olgunlukta tahakkuk ettiğini vurgulamıştır (Ekincikli, 2012, s.161).

TPCF ile ilgili olarak şu bilgi de paylaşılmalıdır. Fırkaları kapatılan mebuslar, firka meclisi grubu olarak çalışmalarını sürdürmüşlerdir. Fakat aralarında bir grup disiplini mevcut olmamıştır. Zaten Takrir-i Sükûn Kanunu'ndan sonra meclise bir durgunluk havası hâkim olmuştur (Çakan, 1999, s. 425). TPCF'nin oy kullanma tercihleri ve istatistikleri bağlamında ele alındığı bir çalışmada TPCF mensuplarının firkalarının kapatılmasından sonra da oy kullanma tercihleriyle oldukça sert bir muhalefet sergilediklerine dikkat çekilmiş, böylece meclis grubunun hukuken dağıtılmış olmasının meclis içindeki muhalefeti dizginlemek açısından herhangi bir tesirinin olmadığı vurgulanmıştır (Demirel, 2000, s. 10).

\section{Sonuç}

Yeni Türk devletinin ilk muhalefet partisi olan TPCF’nin kurulmasında; biri Gazi Mustafa Kemal Paşa ile diğer milli mücadele liderleri arasındaki ihtilaflar sonucu gerçekleşen yol ayrımı, diğeri İkinci Grup mensupları ile bazı İttihatçıların yeni bir faaliyetle ortaya çıkma motivasyonlan olmak üzere iki etkenin büyük rolü olmuştur.

Yeni muhalif firka iktidar çevreleri tarafindan pek de iyi karşılanmamış hatta bazı gazetelerin yoğun bir yıpratma yayınına muhatap kalmıştır. Fırkanın programı eleştirildiği gibi (programın yeni bir şey getirmediği ve CHF'ninkinden farklı olmadığı gibi) firka liderlerinin mazileri ile ilgili birtakım konular da gündeme getirilmek suretiyle etkisizleştirilmeleri ve kamuoyu önünde prestij kaybına uğramaları amaçlanmıştır. Halk Fırkası çevreleri aslında bu yeni firka teşebbüsünü birtakım mülahazalara istinaden vakitsiz ve gereksiz bulmuşlardır. Bir müddet daha tek partili bir idarenin varlığını öncelemiş ve önemsemişlerdir. Yeni partinin teşekkülünden evvel ve sonra ortaya konulan görüşler ve yeni partiye karşı takınılan tutumdan bunu kolaylıkla anlamak mümkündür. Ülkenin İstiklal savaşından yeni çıtığ bir sırada yaralarını sarması ve reformlar yapması, yeni bir Türkiye inşa etmesi gerektiğinden hareketle böyle bir durumda muhalif bir firkanın ortaya çıkması ve faaliyetleri sakıncalı görülmüş ve bu gelişme eski Türkiye'ye dönüş olarak değerlendirilmiştir. Bazı iktidar mensupları ise iktidarın karşısında muhalif bir firka olmasını çok da sorunlu görmemişler, fakat muhalif firkanın kontrolden çıarak güçlenmesini ve bu yönüyle iktidarı tehdit etmesini veya onun yerine geçmesini uygun görmemişlerdir.

Muhalif firka aynı zamanda İttihatçılar için de bir çıkış yolu ve sıçrama tahtası olmuştur. Çeşitli nedenlerle gerçekleşen yol ayrımında ülkenin kurtarılmasında ve yeni Türk devletin kurtulmasında hizmetleri geçen fakat eski güçleri olmayan ve bir toparlanma dönemine girmek isteyen bazı İttihatçılar da Gazi Mustafa Kemal Paşa'nın karşısında yani TPCF safinda yer almışlardır. Aynen CHF'den ayrılan alternatif liderler gibi hizmetleri ile mütenasip bir mevki alamadıklarından dolayı rahatsızlıklarını izhar etmişlerdir.

Sonuç olarak ayrıca belirtilmeli ki TPCF kendi iradesi dışında alınan bir kararla kapatılmış hatta Haziran 1925 'te yapılması planlanan ilk genel kongresini gerçekleștirme imkânı dahi bulamamıștır. O 
Türk Siyasal Hayatının Vakitsiz Doğan Çocuğu: Terakkiperver Cumhuriyet Fırkası/Ersin MÜEZZINOĞLU

günün Türkiye'sinde savaştan ve yıkımdan yeni çıkmış ve demokrasi tecrübesi çok köklü olmayan bir ülkede; Gazi Mustafa Kemal Paşa'nın prestiji, konumu, reformlan ve kazanımlanı (çağdaşlık, laiklik ve millilik temelli reformlar, özellikle Cumhuriyet rejimi ve Hilafetin ilgası gibi) ortada iken bir muhalif firkanın kısa sürede başarılı olmasını beklemek veya sayılan kazanımları riske etmesine göz yummak zaten beklenmezdi. Ayrıca Cumhuriyet rejimi yeni Türk devletinin alamet-i farikası olmakla birlikte bir bakıma bunun ete kemiğe bürünmüşü ve tekamülü olan demokrasi, 1920'lerin ortasında Türkiye'nin içinde bulunduğu ulusal ve uluslararası ortam içerisinde öncelikli bir konu olarak ele alınmamıştır. Türkiye'nin hemen yakınındaki Balkanlardan başlamak üzere Avrupa'da da bu yıllarda ve hemen sonrasında güçlü bir demokrasi varlığı ve bunun sürdürülmesi durumu söz konusu değildir. Akıbeti böyle olmakla birlikte TPCF’nin kuruluşunun, program ve faaliyetlerinin Türkiye'de demokrasi kültürünün gelişmesine katkıda bulunduğu söylenebilir. 
ISSN: $2667-4432$

Journal of Universal History Studies (JUHIS) • Vol. I • Issue 1 • 2018 • pp. 44-79

\section{Kaynakça}

[1] Akşam

[2] Cumhuriyet

[3] Hakimiyet-i Milliye

[4] $\dot{I k d a m}$

[5] Son Telgraf

[6] Tanin

[7] Tevhid-i Efkâr

[8] Vakit

[9] Hayat Tarih Mecmuast

[10] Ahmet Cevdet (Oran), "Son Hadise Hakkında”, İkdam, 11 Şubat 1925, s. 1.

[11] Altay, Fahrettin(1970), 10 Yıl Savaşve Sonrası, İnsel Yayınları, İstanbul.

[12] Atatürk’ün Söylev ve Demeçleri II(1959), Türk İnkılâp Tarihi Enstitüsü Yayınları, Ankara.

[13] Atatürk’ün Söylev ve Demeçleri III(1961), Türk İnk1lap Tarihi Enstitüsü Yayınları, Ankara.

[14] Atatürk, Mustafa Kemal(2010), Nutuk-Söylev, Yay.Haz. İsmail Arar, Uluğ İğdemir, Sami N. Özerdim, Cilt I-II, TTK Basımevi, Ankara.

[15] Atay, Falih Rıfkı(1984), Çankaya, Bateş Yayınları, İstanbul.

[16] Ateş, Nevin Yurdsever(1998), Türkiye Cumhuriyeti'nin Kuruluşu ve Terakkiperver Cumhuriyet Firkası, Der Yayınlan, İstanbul.

[17] Aydemir, Şevket Süreyya(2008), Tek Adam, Cilt 3, Remzi Kitabevi, Ankara.

[18] Babaoğlu, Resul(2012), "Nutuk ve Hatıralar Ekseninde Terakkiperver Cumhuriyet Fırkası Olayı ve Süreci”, Yakn Dönem Türkiye Araştırmaları, Sayı 22, (63-108).

[19] Benizade Hamdi, “Maskeler Aşağı”, Cumhuriyet, 7 Kasım 1924, s. 1.

[20] Benizade Hamdi, "Yeni Frrka”, Cumhuriyet, 23 Ekim 1924, s. 2.

[21] Cebesoy, Ali Fuat(1960), Siyasi Hatıralar, 2.Kısım, Doğan Kardeş Yayınları, İstanbul.

[22] Çakan, Iş1, Türk Parlamento Tarihinde İkinci Meclis(1999), Çağdaş Yayınları, İstanbul.

[23] Demirel, Ahmet(2007), Birinci Meclis te Muhalefet II. Grup, İletişim Yayınları, İstanbul. 
Türk Siyasal Hayatının Vakitsiz Doğan Çocuğu: Terakkiperver Cumhuriyet Fırkası/Ersin MÜEZZINOĞLU

[24] Demirel, Meral(2000), “TPCF Milletvekilleri Mecliste Nasil Oy Kullandı?" Tarih ve Toplum, say1 196, (6-12).

[25] Ekincikli, Mustafa(2012), “Türk Demokrasi Kültürünün Gelişim Sürecinde Terakkiperver Cumhuriyet Fırkası'nın Kuruluşu”, Gazi Akademik Bakış, sayı 11, (151163).

[26] Erer, Tekin(1963), Türkiye'de Parti Kavgaları, Cilt 1, Ticaret Postası Matbaas1, İstanbul.

[27] Falih Rıfkı (Atay), “Demir El”, Hakimiyet-i-i Milliye, 26 Şubat 1925, s. 1.

[28] Falih Rıfkı (Atay), "Hâlâ mı Münafiklık”, Hakimiyet-i Milliye, 27 Şubat 1925, s. 1.

[29] Falih Rıfkı(Atay), “Kendi Mantıklanyla İskat”, Cumhuriyet, 21 Kasım 1924, s. 2.

[30] Falih Rufkı (Atay), "Maskaralık”, Cumhuriyet, 16 Kasım 1924, s. 2

[31] Falih Rufkı(Atay), “Sed Kararnamesi”, Hâkimiyet-i Milliye, 5 Haziran 1925. s. 1.

[32] Falih Rıfkı (Atay), "Son Ders”, Hâkimiyet-i Milliye, 14 Mayıs 1925, s. 1.

[33] Fevzi Lütfi, “'̇̇smet Paşa’nın İstifası”, Son Telgraf, 22 Kasım 1924, s. 1

[34] Goloğlu, Mahmut(2007), Devrimler ve Tepkileri(1924-1930), Türkiye İş Bankası Yayınları, İstanbul.

[35] Hüseyin Cahit (Yalçın), "Fırkada”, Tanin, 12 Kasım 1924, s. 1.

[36] Hüseyin Cahit(Yalçın), 'Korkunç Bir Manzara, Tanin, 15 Kasım 1924, s. 1.

[37] Hüseyin Cahit(Yalçın), “Malta Hatıraları”, Tanin, 7 Mart 1925, s. 1.

[38] Kalafat, Yaşar(1992), Şark Meselesi Işığında Şeyh Sait Olayı, Karakteri, Dönemindeki İç ve Dış Olaylar, Boğaziçi Yayınlan, Ankara.

[39] Karabekir, Kazım(1995), İstiklal Harbimizin Esasları, Emre Yayınlanı, İstanbul.

[40] Karabekir, Kazım(2006), İstiklal Harbimiz, Cilt: 1-2, Yapı Kredi Yayınlan, İstanbul.

[41] Karaosmanoğlu, Yakup Kadri(1984), Politikada 45 Yll, İletişim Yayınları, İstanbul.

[42] Karpat, Kemal(1967), Türk Demokrasi Tarihi, İstanbul Matbaası, İstanbul.

[43] Koç, Nurgün(2013), “Şeyh Sait Ayaklanması”, Turkish Studies, Volume 8/2, (153-166).

[44] Koç, Nurgün(2013), "Terakkiperver Cumhuriyet Fırkası ile ilgili Gelişmeler", TürkIslam Medeniyeti Akademik Araştırmaları Dergisi, sayı 16, (75-84).

[45] Mahmut (Soydan), “İstiklal Mahkemeleri”, Hâkimiyet-i Milliye, 15 Mart 1925, s. 1. 
ISSN: $2667-4432$

Journal of Universal History Studies (JUHIS) • Vol. I • Issue 1 • 2018 • pp. 44-79

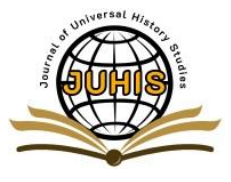

[46] Mahmut (Soydan), “Sükût-1 Hayal”, Hakimiyet-i Milliye, 8 Haziran 1925, s. 1.

[47] Mahmut (Soydan), 'Takrir-i Sükûn”, Hakimiyet-i Milliye, 6 Mart 1925, s. 1.

[48] Mahmut (Soydan), "Vaziyetin Tahlili", Hakimiyet-i Milliye, 17 Mart 1925, s. 1.

[49] Mehmet Asım, "Eski İttihat ve Terakki Yeni Bir programla Faaliyet Sahasına Geçebilir mi?’ Vakit, 6 Ekim 1924, s.1.

[50] Mehmet Asım, “İntizar Vaziyeti”, Vakit, 30 Ekim 1924, s. 2.

[51] Mehmet Asım, "Karabekir Paşa Mecliste”, Vakit, 29 Ekim 1924, s. 1.

[52] Mehmet Asım, "Siyasi Edebiyatı Bırakalım Asıl Derde Bakalım”, Vakit, 29 Aralık 1924, s. 1

[53] Mehmet Asım, “Terakkiperverlerin Kongresi”, Vakit, 19 Mayıs 1925, s. 2.

[54] Mehmet Asım, "Yeni Firka ve Merkez Bahsi”, Vakit, 1 Aralık 1924, s. 1

[55] Müezzinoğlu, Ersin(2012), Bir İttihatçı Eğitimci Ahmet Şükrü Bey, Erciyes Üniversitesi, Kayseri.(Yayınlanmamış Doktora Tezi)

[56] Müezzinoğlu, Ersin(2015), "Mahkeme Tutanaklarına Göre İzmir Suikastı ve Ahmet Şükrü Bey”, The Journal of Academic Social Science Studies(JASS), Number 38, (155176).

[57] Orbay, Rauf(2004), Cehennem Değirmeni, Truva Yayınları, İstanbul.

[58] Özdemir, Yavuz(2002), “Şeyh Sait İsyanı”, Yeni Türkiye, sayı 44, Ankara, (481-495).

[59] Sezgin, Ömür ve Saylan, Gencay(1983), Terakkiperver Cumhuriyet Fırkası, Cumhuriyet Dönemi Türkiye Ansiklopedisi, Cilt 8, İletişim Yayınları, İstanbul, (2047-2051).

[60] Tevetoğlu, Fethi(1986), “Terakkiperver Cumhuriyet Firkası”, Türk Kültürü, sayı 264, $(41-46)$.

[61] Tunaya, Tarık Zafer(1952), Türkiye'de Siyasi Partiler (1859-1952), Arba Yayınlan, İstanbul.

[62] Tunçay, Mete(1992), T.C’nde Tek Parti Yönetiminin Kurulması, Cem Yayınevi, İstanbul.

[63] Uzun, Turgay(2002), “Atatürk Dönemi Muhalefet Hareketleri, Türkler, Cilt 16, Yeni Türkiye Yayınları, Ankara, (569-578).

[64] Yakup Kadri(Karaosmanoğlu), "Hesap Günü Gelmiştir”, Hakimiyet-i Milliye, 25 Şubat 1925 s. 1

[65] Yakup Kadri(Karaosmanoğlu), "Yalnız Hakikat Namına”, Hakimiyet-i Milliye, 12 Mayıs 
Türk Siyasal Hayatının Vakitsiz Doğan Çocuğu: Terakkiperver Cumhuriyet Fırkası/Ersin MÜEZZINOĞLU

1925, s. 1.

[66] Yeşil, Ahmet(2015), “Terakkiperver Cumhuriyet Fırkası'nın Kapatılmasında Sondan Bir Önceki Gelişme: TPCF Urfa Siverek Şube Kâtibi Mehmet Fethi Bey’in Şark İstiklal Mahkemesinde Yargilanması", Adlyaman Üniversitesi Sosyal Bilimler Enstitüsü Dergisi, sayı 20, (711-744).

[67] Yeşil, Ahmet(2002), Türkiye'de İlk Teşkilatlı Muhalefet Hareketi Terakkiperver Cumhuriyet Fırkası, Cedit Neşriyat, Ankara.

[68] Yunus Nadi (Abalığlu), “Ahmet Şükrü Beyefendi'nin Cevabına Cevabımız", Cumhuriyet, 28 Aralık 1924, s. 2.

[69] Yunus Nadi (Abahığlu), "İktidar İbtilası”, Cumhuriyet, 2 Kasım 1924, s. 1.

[70] Yunus Nadi (Abalığlu), "Program ve Fırka”, Cumhuriyet, 1 Aralık 1924, s. 1

[71] Yunus Nadi (Abalığlu), “Tereddi İhtimali”, Cumhuriyet, 31 Ekim 1924, s. 1.

[72] Yunus Nadi (Abalıoğlu), "Şükrü Bey’in Beyanatı”, Cumhuriyet, 25 Aralık 1924, s. 1

[73] Yüceer, Saime(1999), "Cumhuriyet Dönemi Çok Partili Hayata Geçiş Sürecinde İlk Girişim: Terakkiperver Cumhuriyet Fırkası”, Türkler, Cilt 16, Yeni Türkiye Yayınlanı, Ankara, (534-545).

[74] Zürcher, Eric Jan(1988), “Atatürk ve Muhalefet, 1924’teki Çok Partili Demokrasi”, Tarih ve Toplum, say149, (16-19).

[75] Zürcher, Eric Jan(2007), Cumhuriyetin İk Yllarında Siyasal Muhalefet Terakkiperver Cumhuriyet Fırkası (1924-1925), İletişim Yayınları, İstanbul. 